УДК 82.0

DOI 10.22455/2541-7894-2019-6-134-186

\title{
Анастасия ГЛАДОЩУК
}

\section{ПРОЗА ХУЛИО КОРТАСАРА И ФРАНЦУЗСКИЙ «НОВЫЙ РОМАН»}

Аннотация: Статья посвящена проблеме влияния французского «нового романа» в лице А. Роб-Грийе (1922-2008), М. Бютора (1928-2016) и Н. Саррот (1900-1999) на формирование поэтики их аргентинского современника, одного из создателей «нового» латиноамериканского романа - Хулио Кортасара (1914-1984). Обращение к малоизвестным теоретическим работам писателя («Теория туннеля», «Положение романа») дает возможность представить развитие «нового романа» в Старом и Новом Свете как синхронный процесс: Кортасар объявляет войну таким «устаревшим понятиям», как «роман», «персонаж», «психологизм», «сюжет», «когерентность», «пространственно-временной континуум», пассивный «читатель», независимо от французских коллег. Совпадая с ними в выборе «ориентиров» и «контрориентиров», Кортасар никогда не скрывал своего интереса к теории «нового романа». Детальный сравнительный анализ декларируемых «новороманистами» художественных принципов и их реализации в творческой практике позволяет установить многочисленные параллели (вплоть до общности формулировок), доказывающие, что Кортасар, Роб-Грийе, Бютор и Саррот шли в одном направлении и преследовали общие цели («антироман», «новый человек», «новый язык», непосредственность восприятия). Разделяя стремление Саррот выйти на надличностный психологический уровень, Кортасар ведет игру с пространственно-временными планами параллельно с Бютором и ищет, подобно Роб-Грийе, «остранения» от повседневной логики и иерархии субъект-объектных отношений. Выявляемое сходство дает также возможность раскрыть своеобразие кортасаровской поэтики, обусловленное его особым мировидением, осуществляемым им на протяжении всего творчества поиском «новой этики» и «новой метафизики». Кортасар гораздо большее значение придавал неэстетической, гносеологической, экзистенциальной функции литературы.

Ключевые слова: Хулио Кортасар, Натали Саррот, Мишель Бютор, Ален Роб-Грийе, «новый роман», теория «антиромана», «устаревшие понятия», эксперимент, франко-латиноамериканские литературные связи, рецепция.

(C) 2019 Анастасия Валерьевна Гладощук (кандидат филол. наук; Московский государственный университет им. М.В. Ломоносова, Россия) appletart@mail.ru 
UDC 82.0

DOI 10.22455/2541-7894-2019-6-134-186

\section{Anastasia GLADOSHCHUK}

\section{JULIO CORTÁZAR'S PROSE AND THE FRENCH NOUVEAU ROMAN}

Abstract: The paper is centred on the problem of influence of the French nouveau roman represented by A. Robbe-Grillet (1922-2008), M. Butor (1928-2016) and N. Sarraute (1900-1999) on the aesthetic formation of their Argentine contemporary, one of the creators of the new Latin American novel - Julio Cortázar (1914-1984). Considering Cortázar's little known theoretical works (The Tunnel Theory, Novel's Condition), the development of the new novel in the Old and the New World can be seen as a simultaneous process: Cortázar challenges "obsolete notions", such as "novel", "character", "psychologism", "story", "coherence”, "space-time continuum", "passive reader" independently from his French colleagues. Coinciding in the choice of the models he follows or rejects, Cortázar has never hid his interest in the theory of the nouveau roman. A detailed analysis of the artistic principles declared by the new novelists and their creative realizations permits to trace numerous parallels (including full coincidence of the statements) that prove that Cortázar, Robbe-Grillet, Butor and Sarraute followed one direction and shared ideas ("antinovel", "new man", "new language", direct perception). Seeking, as did Sarraute, to reach a transpersonal psychological sphere, Cortázar plays with time and space together with Butor, and tries to digress an everyday logic and reverse relations between subject and object, similarly to Robbe-Grillet. These affinities bring to light Cortázar's originality, which is determined by his peculiar world view, his life-long search of "new ethics" and "new metaphysics". Cortázar pays much more attention to non-aesthetic, gnoseological, existential values of literature.

Keywords: Julio Cortázar, Nathalie Sarraute, Michel Butor, Alain Robbe-Grillet, new novel, theory of anti-novel, "obsolete notions", experiment, French-Latin American literary contacts, reception.

(C) 2019 Anastasia V. Gladoshchuk (PhD; M.V. Lomonosov State University of Moscow, Russia) appletart@mail.ru 
Понятие «нового» латиноамериканского романа, прочно вошедшее в литературоведческий обиход в 60-е гг. XX в., делает проблематичным не только амбивалентность критерия «новизны» («новым» латиноамериканский роман был как в сознании его творцов, так и в восприятии иностранных читателей и критиков ${ }^{1}$ : небывалый успех латиноамериканских авторов, сопровождавшийся соответствующим издательским «бумом», спровоцировал своего рода литературное «открытие Америки»), но и параллельное существование французского «двойника». Что стоит за общим наименованием, является ли оно результатом игры отражений, которую со времен Конкисты ведут между собой Старый и Новый свет? Или же его можно считать простым терминологическим совпадением? ${ }^{2}$

Проблема отношения «нового» латиноамериканского романа к «новому роману» французскому встает особенно остро в случае Хулио Кортасара (1914-1984), решительно связавшего свою судьбу с Францией, на языке которой он, в силу обстоятельств рождения, заговорил даже раньше, чем на испанском. Символично, что первая поездка писателя в Париж, состоявшаяся в 1950 г., была ознаменована «встречей» с признанным предшественником «нового романа»: прогуливаясь по набережной Сены, Кортасар заметил на лотке букиниста роман «Мерфи» (Murphy, 1938; франц. перевод 1947), автором которого был незнакомый ему господин по имени Сэмюэль Беккет - книга ему чем-то понравилась, и он решил ее купить. Именно к этому тексту вспоминал впоследствии писатель - восходит образ буэнос-айресского сумасшедшего дома в романе «Игра в классики» (Rayuela, 1963) над которым он будет работать, уже окончательно переселившись в Париж ${ }^{4}$. Как и в случае многих других латиноамериканских авторов,

1 Cf. Pollman, L. "La nueva novela hispanoamericana. Un balance definitorio." Revista chilena de literatura 34 (Nov. 1989): 77.

2 Немецкий литературовед Лео Польман, автор фундаментального сопоставительного исследования «“Новый роман” во Франции и в Ибероамерике» (1968; исп. перевод 1971), рассматривая «новый роман» французский и «новый роман» латиноамериканский в перспективе общей эволюции жанра как две линии «нового романа» в широком смысле, считает, что теория влияний с той или другой стороны несостоятельна (Pollmann, L. La «nueva novela» en Francia y en Iberoamérica. Madrid: Gredos, 1971).

3 Hernández, A.M. “Conversación con Julio Cortázar.” Cortázar, J. Rayuela, ed. Julio Ortega y Saúl Yurkievich. Madrid: ALLCA XX, 1991: 730.

4 Интересна история создания романа. Как рассказывал Кортасар в интервью уругвайскому писателю и журналисту Омару Прего, в один очень жаркий летний 
«парижская культура» стала катализатором творческой активности Кортасара. Обозначим основные вехи его писательского пути.

До переезда в Европу Кортасар печатается мало: в 1949 г. выходит драматическая поэма «Короли» (Los reyes), в 1951 г. - сборник рассказов «Бестиарий» (Bestiario $)^{5}$. После 1951 г. одна публикация следует за другой: в 1956 г. увидит свет первое издание сборника рассказов «Конец игры» (Final del juego) (второе, расширенное издание выйдет в 1964 г.), в 1959 г. - сборник «Тайное оружие» (Las armas secretas). В 1960 г. Кортасар издает роман «Выигрыши» (Los premios), который он демонстративно начинает знаменитой по «Манифесту сюрреализма» (1924) Андре Бретона и «Эре подозрения» (L’Ère du soupçon, 1950, 1956) Натали Саррот фразой «Маркиза вышла в пять часов» ${ }^{6}$. Делая первые шаги на пути к тому, что сам Кортасар поначалу называл «антироманом», он наносит пробный удар по композиции: пронумерованные главы перемежаются с главами, обозначенными буквами алфавита, в первых развивается действие, во-вторых - поэтические монологи самого пассивного из героев (Персио), посредством которых Кортасар пытался показать событийный ряд в ином концептуальном ракурсе (философском, метафизическом) и стилистическом регистре. Сходный принцип комбинирования разных языков и оптик станет структурообразующим и для «Игры в классики». О своем следующем романе - «62: Модель для сборки» (62/Modelo para armar, 1968), в котором реализу-

день (он не помнит точно, было ли это в Буэнос-Айресе или в Париже, но, скорее всего, в Буэнос-Айресе) он увидел перед собой группу персонажей, которые совершали действия «одно другого абсурднее», пытаясь передать из окна в окно двух разделенных улицей домов кулёк с мате и гвозди. Написав этот текст - ставший впоследствии 41 главой романа, так называемой «главой с доской»- Кортасар понял, что это не рассказ и что у главного героя, которого он, ни секунды не колеблясь, назвал Орасио Оливейра, есть парижское прошлое, поэтому он должен оставить Буэнос-Айрес и отправиться на поиски Оливейры в Париж: что Кортасар в действительности и делает. (Prego, O. Fascinación de las palabras: Conversaciones con Julio Cortázar. Barcelona: Muchnik Editores, 1985: 109.)

5 «Экзамен» (Examen) не был принят к печати из-за нарушений языковых норм и отсутствия четкой логической структуры, о чем Кортасар всегда сожалел, так как, по его словам, в этом романе он осмелился сделать в плане письма то, что впоследствии ему, быть может, не удалось повторить.

6 Так же начинает свой роман «Маркиза вышла в пять» (La Marquise sortit à cinq heures, 1961) Клод Мориак, принимая вызов, брошенный Бретоном и Полем Валери. Если Натали Саррот говорила, что «писать романы - это отказаться писать “Маркиза вышла в пять часов”» (Sarraute, N. Evvres complètes. P.: Gallimard, 1996: 1684.), Кортасар и Мориак независимо друг от друга опровергают это утверждение (при том что Кортасар это сделал раньше). 
ется замысел Морелли, изложенный в 62 главе «Игры...»- Кортасар говорил: «Если я что-то и позаимствовал у “нового романа”, то искать это следует в “62”» романистов и поэтикой романа является «антипсихологизм»: Кортасар хотел изобразить группу персонажей, чувства и поступки которых не зависели бы от них самих, а подчинялись законам иного, не-человеческого порядка. Антипсихологизм требовал «антипространства» и «антивремени»: описываемые события происходят одновременно в трех местах - Париже, Вене, Лондоне. Параллельно реальному городскому пространству существует ирреальное пространство Города, в котором персонажи могут встречаться независимо от своего местоположения. Бесконечно-одинаковые гостиничные номера в отелях Города, похожие друг на друга дома, улицы, лица людей в трамваях, навязчиво повторяющиеся образы куклы, василиска, перевязанного тесемкой свертка все это создает атмосферу, очень напоминающую атмосферу романов Роб-Грийе. Последний роман Кортасара - «Книга Мануэля» (Libro de Manuel, 1973) - заметно уступает другим его текстам ${ }^{8}$, но все же не отстает от них в плане техники. Композиционно роман представляет собой в прямом смысле слова коллаж: по сюжету, «книга Мануэля» это альбом, в который Сусана - а вместе с ней и все остальные члены интернациональной революционной организации «Хода» - вклеивает разнообразные газетные вырезки для своего маленького сына Мануэля, чтобы он нашел в нем «моментальный портрет того мира, который они стремятся изменить» ${ }^{9}$. Так же поступает и сам Кортасар: фотографически воспроизведенные заметки, документы и телеграммы вмонтированы прямо в текст, для того чтобы читатель оказался на месте читающих героев, в актуальном для них времени.

Оценивая новаторство и динамику развития поэтики Кортасара, невозможно не задаться вопросом: повлияла ли на ее формирование деятельность французских новороманистов? Об этом писателя спра-

7 Prego, O. Fascinación de las palabras: 94.

8 Сам Кортасар прекрасно это понимал и говорил, что «Книга Мануэля» худшее его произведение, но на момент работы над текстом он ставил перед собой другие цели: своим романом он хотел привлечь внимание к чудовищной эскалации насилия в странах Латинской Америки (в 70-х гг. писатель активно участвовал в политической жизни континента). Кортасар отказался от авторских прав на роман, поэтому все деньги, вырученные при продаже, пошли в фонд помощи политзаключенным.

9 Кутейщикова В.Н., Осповат Л.С. Новый латиноамериканский роман: 50-70-е гг. М.: Советский писатель, 1983. С.285. 
шивали во многих интервью. Так, например, беседуя с Эвелин Пикон Гарфилд, Кортасар говорил: «Не думаю, что французский “новый роман” оказал существенное влияние на “62", или на другие мои тексты, потому что, хотя меня очень заинтересовала теория “нового романа”, в той мере, в какой она является попыткой преобразовать литературное поле в ситуации пресыщения, вызываемого определенной, ставшей традиционной во Франции, романной моделью, сама по себе литературная практика, сами романы - романы Роб-Грийе, Бютора, Натали Саррот, Клода Симона - никогда не вызывали у меня особого интереса. К тому же они, как мне кажется, начали печататься в то время, когда я отходил от чтения романов и все больше читал поэзию, философию и антропологию. Теория же, напротив, да, очень меня заинтересовала и некоторые романы, например, Натали Саррот: я всегда читал ее очень внимательно, поскольку, как мне кажется, вместе с одним-двумя романами Роб-Грийе, это, возможно, лучшее, что дал французский “новый роман”. Но я все же думаю, что другого рода литературные эксперименты могли больше, гораздо больше повлиять на меня, чем “новый роман” этих последних лет» ${ }^{10}$. Примечателен следующий факт: когда речь зашла о романе «Распределение времени» (L'emploi du temps, 1956) Бютора, Кортасар сказал Эвелине, что не читал его ${ }^{11}$. Но четырьмя годами ранее, в интервью журналу Quinzaine littéraire, он утверждал обратное: «У Бютора я читал "Изменение" и "Распределение времени": в них осуществлены очень интересные эксперименты, но не в том направлении, в котором шел я сам» ${ }^{12}$. Из этого следует, что Кортасар забыл о прочитанном им «новом романе». Не случайно во время одного из последних своих интервью он признавался: «В моей памяти мало что оставалось от прочитанной книги, a то, что оставалось, лежало, как мертвый груз» ${ }^{13}$. Однако эти слова не отменяют отмеченного ранее: Кортасара заинтересовала теория «нового романа» - в той мере, в какой она попадала в резонанс с его собственными исканиями и концепциями, сформулированными еще до приезда во Францию.

10 Picón Garfield, E. Cortázar por Cortázar. Xalapa: Universidad Veracruzana, 1981: 87-88.

11 Ibid.: 82 .

12 Bjurström, C.G. "Entretien avec Julio Cortázar." Archivo Julio Cortázar. CRLA Archivos (Poitiers): 22. - URL: http:// www.mshs.univ-poitiers.fr/crla/contenidos/ Cortazar/image.php?Id_img=5292\&Code=28.007.

13 Prego, O. Fascinación de las palabras: 92-93. 
С января по август 1947 г. Кортасар работает над «Теорией туннеля» (Teoría del túnel) ${ }^{14}$, идейную основу которой - на что указывает подзаголовок - составляют «Заметки о положении сюрреализма и экзистенциализма» (Notas para una ubicación del surrealismo y del existencialismo). Являясь самым объемным теоретическим текстом Кортасара, эта книга оставалась неизданной вплоть до 1994 г., когда издательство Alfaguara выпустило трехтомное собрание его критических работ ${ }^{15}$; при жизни писателя увидела свет только ее часть: эссе «Заметки о современном романе» ("Notas sobre la novela contemporánea”, $1948)^{16}$, опубликованное в буэнос-айресском журнале Realidad: Revista de Ideas (№8), является компиляцией глав «Роман-морская свинка» (“Un cobayo: la novela”) и «Этеокл и Полиник» (“Etéocles у Polinices”). Представляя свой взгляд на историю западного романа и подробно анализируя этапы его развития с 1900 по 1940 гг., Кортасар готовит почву для собственного творчества, закладывает основы своей поэтики: изложенная в «Теории туннеля» концепция романа через 15 лет найдет выражение в «Игре в классики». Не менее важным для реконструкции траектории теоретической мысли Кортасара является эссе «Положение романа» (“Situación de la novela”, 1950), напечатанное на страницах крупного мексиканского журнала Cuadernos Americanos ${ }^{17}$.

Названные работы свидетельствуют о том, что за несколько лет до и независимо от французских новороманистов Кортасар заговорил о необходимости преобразования языка жанра, об отсутствии в современных романах персонажей и «реакции» на традиционный психологизм. Среди прочего его внимание привлекали основоположники американского «крутого детектива»: Джеймс М. Кейн, Дэшил Хэммет и Рэймонд Чандлер. Характеристика, которую он дает их манере пись-

14 Объяснение заглавного образа, емко выражающего базовый принцип авангардного искусства, мы находим в одноименной главе книги: разрушать, чтобы созидать, как это происходит при строительстве туннеля (Cortázar, J. Obra crítica I. Madrid: Alfaguara, 1994: 66). Через несколько лет Роб-Грийе сформулирует ту же антиномию в эссе «От реализма - к реальности» (“Du réalisme à la réalité”, 1955, 1963): «Роман... уже сейчас осуществляет слияние обоих понятий в некоторых парах противоположностей: содержание-форма, объективность-субъективность, смысл-абсурд, созидание-разрушение, память-настоящее время, воображениедействительность». (Роб-Грийе А. Романески. М.: Ладомир, 2005. С. 604.)

15 Cortázar, J. Obra crítica I.

16 Cortázar, J. Obra crítica II. Madrid: Alfaguara, 1994: 141-150.

17 Cortázar, J. "Posición de la novela." Cuadernos Americanos. 52:4 (Julio-agosto 1950): 223-243; Cortázar, J. Obra crítica II: 215-241. 
ма, чрезвычайно напоминает будущий стиль Роб-Грийе: американцы стремятся к представлению фактов такими, какие они есть, без примеси риторики и психологии, так что «между вещью и нами - минимум языка, тот минимум, который необходим, чтобы ее показать» ${ }^{18}$. Наметившиеся таким образом еще до отьезда Кортасара в Париж параллели с теорией «нового романа» найдут продолжение в метатекстовых главах «Игры в классики». Возможно, именно поэтому в одной из них говорится: «Теории Морелли не совсем оригинальны» ${ }^{19}$.

Как удалось аргентинскому писателю опередить или, по крайней мере, не отстать от французских новороманистов? На этот вопрос можно было бы ответить, сославшись на знаменитую лекцию Х.Л. Борхеса «Аргентинский писатель и традиция» ("El Escritor argentino у la tradición”, 1951) ${ }^{20}$, главная мысль которой заключается в том, что аргентинская традиция - это вся западная культура, и аргентинцы имеют на нее даже больше прав, чем европейцы: осознание своей инаковости позволяет им быть менее «почтительными» по отношению к этой культуре и с большей легкостью привносить в нее что-то новое (в сходном положении находятся евреи и ирландцы). Синхронизируясь с литературным процессом Старого Света, Кортасар, круг чтения которого мало чем отличался от круга чтения его французских коллег, совпал с ними также в выборе «ориентиров» (модернистский роман в лице Дж.Джойса, М.Пруста, У.Фолкнера, Ф.Кафки $\left.{ }^{21}\right)$ и «контрориентиров» (роман «бальзаковского типа», массовая литература, паразитирующая на традиционных формах литературы высокой) 22 .

\footnotetext{
18 Cortázar, J. Obra crítica II: 239.

19 Cortázar, J. Rayuela. Madrid: Cátedra, 2012: 613.

20 Borges, J.L. Discusión. Buenos Aires: Emecé Editores, 1972: 160-161.
}

21 Натали Саррот в лекции «Язык в искусстве романа» (“Le langage dans l'art du roman”, 1969) указывала на то, что корни «нового романа» надо искать в первой четверти XX века: новороманисты продолжили начатое Джойсом, Прустом, Кафкой - так же рассуждал и Роб-Грийе. Разговор с Саррот в поезде, увозившем их летом 1956 г. в Шато д’Э на коллоквиум, посвященный обсуждению вопроса «Кончился ли послевоенный период?», убедил писателя в том, что они должны заключить союз и что «новый роман» будет многогранным: Саррот продолжала линию Пруста, сам Роб-Грийе - Кафки, Бютор - Джойса, а Симон - Фолкнера.

22 По всей видимости, новороманисты не воспринимали жившего и творившего рядом с ними Кортасара как конкурента или единомышленника (если они вообще о нем знали). На знаменитом коллоквиуме новороманистов, состоявшемся в последней декаде июля 1971 г. в Серизи-ла-Саль, о нем вспоминают лишь один раз: во время одной из дискуссий Клод Оллье заметил, что было бы интересно провести исследование с целью найти «современных зарубежных 
Заметим, что проблема отношения Кортасара к французскому «новому роману» становилась предметом очень немногих исследований. Интересно, что с одним из них был знаком сам Кортасар: в 1976 г. исследовательница из Кембриджского университета Энн Дункан прислала писателю текст своей статьи «Зеркала и лабиринты: опыт сравнения Кортасара и “нового романа"» ("Mirrors and labyrinths, some comparisons between Cortázar and the 'Nouveau Roman"'). Рукопись с собственноручными пометами Кортасара на полях хранится в архиве Центра латиноамериканских исследований университета Пуатье, и мы читали именно ее. На материале главным образом романа «62. Модель для сборки» Дункан выявляет интересные тематические и образные параллели между кортасаровским текстом и практикой «нового романа»: мотив отсутствия; мотив «пустого центра»; купленная героем Кортасара книга Бютора, упоминаемая в самом начале «62», соотносится с книгой, которую берет с собой в поезд герой бюторовского романа «Изменение» (Modification, 1957) Леон Дельмон - это наблюдение, должно быть, понравилось Кортасару, так как он написал напротив по-французски “Tiens!"23.

Следующая по времени из найденных нами работ относится к 2002 г.: французская исследовательница Даниэль Перро подробно анализирует, опять же, роман «62. Модель для сборки», пытаясь выявить в нем техники, рассматриваемые ею в качестве «минимальной поэтики» «нового романа» (обнажение фикциональной природы рассказа, текст как «рок» персонажа, нарушения хронологии), и тем самым ответить на вопрос, вынесенный в заглавие статьи: является ли роман Кортасара «новым романом»? ${ }^{24}$ Единственный недостаток

писателей, чьи произведения могли бы послужить нам в качестве ориентиров или обнаруживают с нашими черты сходства. Я думаю о латиноамериканских писателях: Борхесе, конечно, Бьой-Касаресе и более близком к нам Кортасаре» (Nouveau roman: hier, aujourd'hui. T.1. Problèmes généraux. P.: Hermann Éditeurs, 2011: 362). В трехтомном издании интервью Бютора, охватывающем промежуток с 1956 по 1996 гг., мы находим только одно упоминание о Кортасаре, в контексте разговора о фантастической литературе.

23 Duncan, J.A. "Mirrors and Labyrinths, Some Comparisons between Cortázar and the 'Nouveau Roman'." Archivo Julio Cortázar. CRLA Archivos (Poitiers). URL: http:// www.mshs.univ-poitiers.fr/crla/contenidos/Cortazar/image.php?Id_ img $=3159 \&$ Code $=16.05$

24 Perrot, D. “'62-Maquette à monter' de Julio Cortázar : un «nouveau roman?” Archivo Julio Cortázar. CRLA Archivos (Poitiers). - URL: http://www.mshs.univpoitiers.fr/crla/contenidos/Cortazar/fiche.php?Code $=16.027 \&$ Cle $=$ catalogue 
этого очень глубокого исследования состоит в том, что оно слишком «постструктуралистское»: все, вплоть до отношений персонажей, интерпретируется через «текст». Примечательно, что обе исследовательницы, формулируя отличие Кортасара от «нового романа», приходят к сходному выводу: парафразируя название четвертого романа РобГрийе, можно сказать, что Кортасар находит выход из «лабиринта». У Кортасара зеркала - это в то же время и окна.

В советской науке в силу идеологических установок делался акцент на оригинальности и самобытности новейшей литературы латиноамериканских стран, а ее формирование ставилось в зависимость от победы кубинской революции. Примечательно, что в статье «Теоретические искания и проблема национального своеобразия литературы в Латинской Америке» (1975) И.А. Тертерян в искаженном свете представляет концепцию американского литературоведа Мануэля Педро Гонсалеса - одного из участников состоявшегося в апреле 1966 г. коллоквиума в Вашингтонском университете в Сент-Луисе, который обозначил первую стадию теоретического осмысления «нового» латиноамериканского романа как художественного феномена. Обвиняя поколение молодых писателей в подражательности, стилизации, бесплодном копировании чужих трафаретов, Гонсалес утверждал, что наибольшее влияние на латиноамериканскую литературу оказывает литература ее северного соседа (заметим, что конкретно Кортасара Гонсалес считает эпигоном Джойса). Относительно же влияния французского «нового романа» исследователь говорил следующее: несмотря на то, что произведения новороманистов активно читаются и комментируются, он сомневается в том, что их манера письма может прижиться на американской почве, так как она «слишком скучна» и не настолько «экстравагантна и гротескна», чтобы латиноамериканские романисты захотели ей подражать ${ }^{25}$. Из обзора Тертерян, напротив, следует, что Гонсалес считает латиноамериканских авторов адептами французского «нового романа» ${ }^{26}$. Не исключено, что эта ошибка была допущена исследовательницей сознательно, так как она давала ей возможность через критику позиции Гонсалеса высветить оригиналь-

25 González, M.P. "La novela hispanoamericana en el contexto de la internacional." Coloquio sobre la novela hispanoamericana. México: Fondo de Cultura Económica, 1967: 55.

26 Тертерян И.А. Теоретические искания и проблема национального своеобразия литературы в Латинской Америке // Теории, школы, концепции. Художественный процесс и идеологическая борьба. М.: Наука, 1975. С. 219. 
ность «нового» латиноамериканского романа на фоне другого «нового» романа.

В предисловии к первому русскому переводу «Игры в классики» Тертерян формулировала следующую мысль: Кортасар и новороманисты шли в разных направлениях от общей «посылки» - признания необходимости преобразования традиционной формы романного повествования ${ }^{27}$. С нашей же точки зрения, вернее было бы сказать, что Кортасар и новороманисты шли в одном направлении, но в разных плоскостях. Это мы и попытаемся доказать в данной работе, проведя сравнительный анализ теоретических установок Кортасара и трех главных представителей французского «нового романа»-А. Роб-Грийе (1922-2008), Н. Саррот (1900-1999) и М. Бютора (1928-2016) - в соотношении с их романной практикой. Обращение к кортасаровским рассказам оправдано тем, что они, по словам автора, сделаны из того же «материала» (“estofa"28), что и романы. Большинство цитируемых текстов (как на испанском, так и на французском) дается в нашем переводе: заметим, что существующие русские переводы «Игры в классики» часто очень неточно отражают кортасаровский текст. Все цитаты, приводимые по русским изданиям, выверены по оригиналу.

\section{1. Роман/Антироман}

Широкое распространение термин «антироман» (anti-roman) как обозначение «нового романа» в целом получил благодаря Ж-П. Сартру: в предисловии к роману «Портрет неизвестного» (Portrait d'un inconnu, 1948) Натали Саррот Сартр отнес к категории «антироманов», помимо анализируемого «Портрета», романы В.В. Набокова, Ивлина Во и «Фальшивомонетчиков» А.Жида. Надо сказать, что сама писательница этого термина не принимала: когда говорят об «антиромане» - объясняла она в интервью 1967 г. - предполагается, что есть четкое представление о том, каким должен быть «настоящий роман». У нее же такого представления нет: она считает, что все произведения, как и писательские техники, уникальны. Между тем определение «антиромана», которое мы находим в предисловии, принадлежит именно Саррот: писательница рассказывала, что текст предисловия - это плод

27 Тертерян И.А. Главный роман Хулио Кортасара // Кортасар Х. Игра в классики. М.: Художественная литература, 1986. С.10.

28 Cortázar, J. La vuelta al día en ochenta mundos. México: Siglo XXI Editores, 1968: 25 . 
их долгих с Сартром бесед, поэтому часть идей принадлежит ему (все, что касается феноменологического противопоставления общего и частного, объективного и субъективного), а часть - ей самой ${ }^{29}$. Так, «антироман» сохраняет «вид и очертания» романа, но это - лишь видимость, обман: речь идет о том, чтобы «оспорить роман с его же помощью, разрушить его на наших глазах в течение того времени, когда он, как кажется, создается, написать роман романа, который не осуществляется, который не может осуществиться» ${ }^{30}$. «Оспорить роман с его же помощью» - именно так можно было бы определить задачу, которую ставил перед собой Кортасар при написании «Игры в классики».

Кортасар никогда не отказывался от романа как жанра (хотя само понятие жанра он считал пережитком западного рационализма) и не стремился его разрушить, так как видел в нем очень продуктивную литературную форму: роман он сравнивал с «большим сундуком» ${ }^{31}$, который таит в себе бесчисленные художественные возможности. В его представлении, «чистых» романов не существует: «Роман - это монстр, один из тех монстров, которых человек принимает, кормит, держит рядом с собой; смесь разнородностей, грифон, обращенный в домашнее животное» ${ }^{32}$. Именно эта потенциальная гетерогенность и «всеядность» романа, создававшая благоприятные условия для преодоления закрытости книги, привлекала к себе Кортасара.

Для многих французских «алитераторов» роман, напротив, оказался бесперспективным видом творчества ${ }^{33}$. Так, например, к концу 50-х гг. Бютору стало тесно в границах жанра: в интервью журналу Tel Quel 1962 г. он говорил, что не может продолжать определять свою творческую деятельность этим словом ${ }^{34}$. Кортасаровская вера в роман

29 Sarraute, N. Evres complètes: 1744.

30 Цит. по: Андреев Л.Г. Жан-Поль Сартр. Свободное сознание и ХХ век. М.: Гелеос, 2004. С.359.

31 González Bermejo, E. Conversaciones con Cortázar. Barcelona: Edhasa, 1978: 86.

32 Cortázar, J. Obra crítica I: 81. Кортасаровское определение романа наводит на мысль о Джойсе: писатель предпочитал называть «Улисса» не романом, а «чудовищной книгой».

33 Андреев Л.Г. Современная литература Франции. 60-е гг. М.: Изд-во Московского университета, 1977. С. 49. Произведения Клода Мориака выходят за границы романа и приближаются к драме, «антитеатру». Роб-Грийе в начале 60-х годов создает «кинороманы».

34 Butor, M. Essais sur le roman. P.: Gallimard, 1975: 173-174. Сужая определение 
легко объяснима: жанр романа в латиноамериканской литературе относительно молодой. В колониальную эпоху было запрещено как читать, так и писать романы, поэтому авторы XIX и XX вв. получили в свои руки литературную форму с неистраченным потенциалом.

Кортасара, как и Саррот, термин «антироман» не удовлетворял своей отрицательностью. Показательно, что в тексте суперобложки первого издания «Игры в классики» слово «антироман» заменено на «контрроман». В одном письме к своему издателю, Франсиско Порруа, Кортасар говорил: «Да, я знаю, что “Игра" тоже роман и, возможно, если она чего и стоит, то именно в этом качестве. Но я писал "Игру в классики” как контрроман, и Морелли взял на себя труд твердо сказать об этом...» ${ }^{35}$. Действительно, Мореллиану можно назвать своеобразной поэтикой «контрромана». В одной из глав, которые Кортасар выделял как ключевые, прямо говорится о намерении Морелли создать текст «антироманный» (antinovelístico), хотя и не «антироманический» (antinovelesco) - то, что он называет "roman comique"з6. «Комический роман» - это произведение открытое во всех отношениях: подобный текст даст свободу читателю, сделав его своим сообщником, он будет намекать на существование иных ценностей, содействуя тем самым «антропофании» - «явлению человека». Этот текст будет «небрежным, разрозненным, бессвязным» ${ }^{37}$ - и в силу этого «антироманным». Закономерным образом встает вопрос: что понимает Кортасар под «романическим»? Ответ на него дает эссе «Положение романа». Кортасар объясняет предпочтение, отдаваемое писателями $\mathrm{XX}$ в. романному жанру, тем, что роман - это инструмент, позволяющий овладеть «человеком как личностью, человеком, который живет и чувствует, что

понятия, Бютор указывал на то, что мы можем говорить о романе только в том случае, когда вымышленные элементы соединяются в единый параллельный мир, в единую «историю», которую можно пересказать. Тем не менее, когда его напрямую спросили, считает ли он жанр романа пройденным для себя этапом, он ответил, что нет: хотя он больше не отводит ему абсолютно главенствующей роли, роман отнюдь не остался для него в прошлом - очень медленно, но он пишет один новый роман (Бютор не лишил себя удовольствия ответить каламбуром).

35 Кортасар X. Письма к издателю. М.: Центр книги Рудомино, 2012. С. 39-40.

36 Говоря о “roman comique”, Кортасар вряд ли имел в виду французский комический роман XVII века: французская формулировка снимает серьезность, присущую литературоведческим терминам, и создает иронический эффект. Однако не исключено и то, что Кортасар хотел противопоставить свой "roman comique" французскому "nouveau roman".

37 Cortázar, J. Rayuela: 559. 
живет» ${ }^{38}$. Значит, «романическое» в понимании Кортасара неразрывно связано с «экзистенциальным». Именно поэтому, как думает Оливейpa, Морелли не может отказаться от романной формы и публикует свои произведения, все свои «блуждания», «встречи и не-встречи»: он был по-христиански убежден в том, что индивидуальное спасение невозможно, что ошибки одного пятнают всех - и наоборот.

\section{2. Литература/Реальность}

Порывая с романной традицией XIX в., каждый из новороманистов утверждает свое понимание «реальности» и «реализма». Символично, что именно эти два слова вынесены Роб-Грийе в заглавие эссе «От реализма - к реальности» - своеобразном эпилоге книги «За новый роман» (Pour un nouveau roman, 1963). Роб-Грийе заявлял, что в новом реализме и речи быть не может о «веризме»: интересна не «правдивая» деталь, а деталь, кажущаяся «фальшивой».

Натали Саррот любила повторять фразу Пауля Клее: искусство не воссоздает видимое, но делает его видимым. Этот принцип лежит в основе «нового, искреннего реализма» ${ }^{39}$, который писательница противопоставляет реализму старому. По ее мнению, истинный писатель-реалист «старается снять с того, что он видит, оболочку предвзятых мнений и готовых образов, ту поверхностную реальность, которую все чувствуют и которой все, за неимением лучшего, пользуются, и иногда ему удается открыть что-то доселе неизвестное» ${ }^{40}$. Между писателем и реальностью, таким образом, устанавливаются воинственные отношения: преодолевая «сопротивление» реальности обыденной, он «атакует» реальность неизведанную.

По-своему боролся с реальностью и Кортасар. Когда Гонсалес Бермехо спросил его, какие отношения связывают создаваемый им художественный мир и реальность, нас окружающую, он ответил, что эти

38 Cortázar, J. Obra crítica II: 223.

39 Саррот Н. Тропизмы. Эра подозрения. М.: Полинформ-Талбури, 2000. C. 335 .

40 Sarraute, N. L'Ère du soupçon. P.: Gallimard, 1956: 141. Это стремление Саррот передает своему персонажу, «потенциальному писателю» - Алену Гимье. Алена, в противоположность Жермене Лемер, привлекает «сырое вещество: объекты, люди, воспринятые непосредственно», так, чтобы между объектом и воспринимающим сознанием не было расстояния, не было «решеток», ограничивающих восприятие (Sarraute, N. Le Planétarium. P.: Gallimard, 1959: 248-249). 
отношения по-братски воинственны. Реальность - главная женщина в его жизни, он борется с ней и в то же время она его увлекает, и в этом смысле он - «реалист». Литература, по мысли Кортасара, представляет собой «предприятие по словесному завоеванию реальности» ${ }^{41}$, а литературная эволюция заключается не в изменении форм, а в изменении направления и стратегии этого «завоевания».

То, что, как пишет Роб-Грийе, приковывает внимание современного романиста: «неполные или отделенные от своего употребления предметы, застывшие мгновения, слова, выхваченные из контекста, перекрещивающиеся разговоры - все, что звучит немного фальшиво, чему недостает естественности» ${ }^{42}$, очаровывает Кортасара. Но если Роб-Грийе предостерегает от возможной метафизической интерпретации подобных явлений - его интересует само их беспричинное присутствие - то Кортасар в «отсутствии смысла, нарушении причинно-следственных связей, пустоте» видит проявление чего-то более истинного, чем окружающий нас видимый мир. С наибольшей полнотой это реализуется в романе «62. Модель для сборки». Первый, «матричный» эпизод романа - эпизод в ресторане «Полидор» - развивается из фразы, выхваченной из контекста: «Шато с кровью, пожалуйста», - сказал толстяк-клиент, и в тот же самый момент Хуан, открывший только что купленную им книгу «6 810000 литров воды в секунду» (6 810000 litres d'eau par seconde, 1965) Бютора, прочитал имя Шатобриана.

\section{3. Форма/Содержание}

«Форма» и «содержание» находятся в числе тех «устаревших понятий», против которых выступает Роб-Грийе. Критики, пишет он, обвиняют новороманистов в формализме, понимая под этим чрезмерную сосредоточенность на форме «в ущерб развитию сюжета и смысла рассказанной истории». Но произведение искусства - не коробка, оно ничего в себе не содержит: «В форме симфонии, картины или романа заключается также их смысл, их "глубинное значение”, то есть их содержание». О содержании нельзя говорить как о чем-то независимом от формы: когда писатель думает о будущем романе, он думает прежде

\footnotetext{
41 Cortázar, J. Obra crítica II: 217.

42 Роб-Грийе А. Романески. С. 602.
} 
всего о том, как он будет написан, а «то, что произойдет в книге, приходит после, как бы порожденное самим письмом» ${ }^{43}$. Солидаризуясь с Натали Саррот, Роб-Грийе отсылает к эссе «То, что видят птицы» (“Ce que voient les oiseaux”), в котором формалистами названы те, кто, делая акцент на содержании, использует старые, окостеневшие формы-формулы. Говоря о своих произведениях, писательница подчеркивала, что между формой и содержанием в них существует неразрывная связь. Ощущение - главный объект ее исследования, - сплавляясь воедино с формой ${ }^{44}$, само становится языком. Одно не может существовать без другого: слова дают ощущению жизнь, а оно, в свою очередь, их оживляет ${ }^{45}$. Бютор считал, что работа над формой является первоочередной задачей романиста. Строгая форма «уничтожает дурные наклонности повседневной речи», в которой слова, вещи, события, законы теряют свой смысл. Форма для писателя - особый инструмент, «вроде сетки, силка», с помощью которого он будет исследовать все вокруг, пока неожиданно не поймает то, о чем раньше и не думал - «и мир предстанет ему иным ${ }^{46}$.

Кортасара, как и многих «новых» латиноамериканских романистов, смело экспериментировавших с романной техникой, также обвиняли в формализме, но эти обвинения отягощались упреками в несамостоятельности, вторичности. Отстаивая свои писательские принципы, Кортасар, как и Саррот, призывал отличать «формализм» от «формулизма» ${ }^{47}$. За несколько лет до Роб-Грийе, в эссе «Положение романа» он заявлял: «В романе нет содержания и формы; содержание дает форму, содержание есть форма» ${ }^{48}$. Омар Прего высказал предположение, что, если между поэтикой Кортасара и поэтикой новороманистов существуют какие-то точки соприкосновения, то объясняется это общим для них представлением о том, что литература становится революционной за счет формы, а не содержания, с чем писатель согласился ${ }^{49}$.

\footnotetext{
43 Там же. C. 546-550.

44 Sarraute, N. Evres complètes: 1675.

45 Ibid.: 1691. México: Siglo XXI editores, 1970: 73.

48 Cortázar, J. Obra crítica II: 231.

49 Prego, O. Fascinación de las palabras: 93.
}

46 Бютор М. Роман как исследование. М.: Изд-во МГУ, 2000. С.66.

47 Cortázar, J. "Literatura en la revolución y revolución en la literatura: algunos malentendidos a liquidar." Literatura en la revolución y revolución en la literatura. 


\section{4. Композиция}

Поначалу Кортасар думал над тем, чтобы не сшивать страницы «Игры в классики», но на стадии чтения гранок он отказался от этого намерения («Мне вдруг подумалось, что это ни к чему, а жаль; у такого вида издания, по-моему, есть чудесные возможности» ${ }^{50}$ ). Вместо этого он предложил читателю выбрать один из двух способов прочтения, не исключая возможности других комбинаций, о чем свидетельствует первая фраза «Таблицы для руководства»: «Эта книга в некотором роде - много книг» ${ }^{51}$. О том же говорит Морелли: «Мою книгу каждый может читать, как ему вздумается. Liber Fulguralis, мантические листы и так далее. Я просто располагаю их так, как бы мне хотелось прочитать. Но даже если все и перепутается, кто знает, может, тогда-то и выйдет замечательная книга» ${ }^{52}$. Из писем читателей Кортасар знал, что многие в самом деле читали роман по-своему. Но все же установленному им порядку чтения он придавал огромное значение: «Любая ошибка в отсылках будет неминуемо роковой, поезд рванет по другому пути, и тогда караул - сотня погибших и три сотни раненых» ${ }^{53}$.

Первый способ охватывает две первые части книги: «По ту сторону» и «По эту сторону», главы 1-56 в традиционной последовательности. При втором, нелинейном, способе прочитывается вся книга, все 155 глав: между главами первых двух частей в прихотливом порядке встраиваются так называемые «необязательные главы» из третьей части («С других сторон») - развитие фабулы при этом замедляется, но описываемые события обретают особую философско-лирическую глубину. Особое место среди «необязательных глав» занимают главы метатекстовые - рассуждения старого писателя Морелли - alter ego самого Кортасара - о языке и литературе.

Выбирая первый способ, читатель, как говорил Кортасар, «многое теряет»: он ничего не узнает о Морелли (Морелли упоминается лишь один раз, в 4 главе, как писатель, которым восхищаются Этьен

\footnotetext{
50 Kopmacap X. Письма к издателю. С. 38.

51 Kopmacap X. Игра в классики. М.: АСТ: Астрель; Владимир: ВКТ, 2011.

52 Там же. С. 486.

53 Kopmacap X. Письма к издателю. С. 81.
} C. 15 . 
и Оливейра); Пола ни разу не появляется как действующий персонаж; читатель лишает себя возможности прочитать целую главу на глиглико и трактат Сеферино Пириса (в 55 главе не уточняется, что именно читал ночью Тревелер; Кортасар методично заменил все цитаты из трактата, которыми он отвечает Талите в 133 главе, фразами вроде «И добавил только что вычитанную туманную фразу», «Тревелер пробормотал что-то непонятное $\left.{ }^{54}\right)$. При втором способе теряется, в прямом смысле слова, только 55 глава, но эта потеря условная, так как все, что есть в 55 главе, содержится в главе 133: разговор Тревелера и Талиты воспроизводится дословно, но в нем появляются цитаты из трактата Сеферино. По окончании чтения у читателя первой книги, скорее всего, сложится впечатление, что Оливейра выбросился из окна, так как 56 глава заканчивается следующими словами: «...единственное, что он мог сделать - это робко помахать им правой рукой, и продолжить смотреть на Магу, на Ману, говоря себе, что в конце концов какая-то встреча произошла, хоть она и не могла продлиться дольше этого ужасающе сладостного мига, когда лучше всего, без всякого сомнения, было бы слегка наклониться вперед и не держаться, хлоп все кончено» ${ }^{55}$. У читателя второй книги, напротив, есть все основания думать, что Оливейра не покончил с собой, так как после 56 главы идут еще восемь глав, в которых друзья ухаживают за Орасио, делают ему уколы, ставят компрессы, так как он, судя по всему, бредит и ему представляется, что он вернулся к Хекрептен. Хотя не исключено и обратное: он, как и намеревался, вернулся к Хекрептен, а психиатрическая лечебница ему снится.

Кортасара не раз спрашивали, в чем смысл сложной композиции романа, почему он не расположил главы сразу в той последовательности, которую явно советует выбрать читателю. В интервью Quinzaine littéraire он объяснял, что, стремясь ниспровергнуть некоторые «прописные истины», он начал с ниспровержения читательских привычек, таких как способ чтения книги. Структурой романа автор как бы говорит читателю: «Ты свободен, проснись, ты не находишься во власти Хулио Кортасара, проснись, действуй сам» ${ }^{56}$. Читатель не должен позволять себя гипнотизировать: переход от «хорошо написанной главы» к газетной вырезке или любой другой «безделице» - это, по словам

\footnotetext{
54 Cortázar, J. Rayuela: 484.

55 Ibid.: 509.

56 Bjurström, C.G. Entretien: 20.
} 
Кортасара, своеобразная пощечина. Таким образом, преодолевая композиционную закрытость традиционного романа («как истинное дитя Запада роман довольствуется закрытой структурой» ${ }^{57}$ ), Кортасар призывает читателя перестать быть пассивным: опыт чтения он должен пережить как опыт жизненный. При этом опыт читателя соотносится с опытом самого автора. Второй способ чтения соответствует тому, каким образом книга писалась: по словам Кортасара, он начал роман в будущем, чтобы вернуться в прошлое и приблизиться к настоящему. Так же и читатель, двигаясь по классикам-главам, должен отказаться от привычных представлений о времени и пространстве, выражаемых традиционной последовательностью глав.

Игра с читателем не ограничивается пермутацией. Если точьв-точь следовать данной Кортасаром инструкции, читатель никогда не сможет закончить читать: в конце последней главы - 131 - дается отсылка к главе 58, а она, в свою очередь, отсылает к 131 и так до бесконечности. В чем смысл этой игры? Обратимся к 141 главе романа, в которой дается следующая характеристика произведений Морелли: «Внезапно слова, весь язык, надстройка стиля, семантика, психология, событийность - все устремлялось к ужасающему харакири. [...] И к новому порядку, но безо всяких гарантий: в конце всегда была ниточка, протянутая куда-то туда, выходящая за пределы книги, нацеленная на некое “возможно", на некое “может быть”, на некое “как знать”, и все представления о произведении как о чем-то застывшем взлетают на воздух» ${ }^{58}$. Этой «ниточкой» становится тире, которое Кортасар ставит в таблице для руководства после 131 главы: «В своей знаменитой инструкции, - писал он в письме к Порруа, - я указываю, что в конце вместо точки лучше поставить тире, пусть читатель увидит, что книга остается “открытой”, и поймет весь смысл игры с финальными качелями от 131 главы к 58 и снова к 131 и так без конца» ${ }^{59}$.

О том, чтобы сделать структуру романа подвижной, мечтал и Мишель Бютор. В конце своего эссе «Исследование о технике романа», опубликованном 19 декабря 1963 г. в журнале Les lettres françaises, он ставит вопрос о возможности «предусмотреть в здании романа различные пути чтения, как в соборе или городе». Бютор подчеркивает, что писатель при этом «должен управлять произведением во всех

57 Cortázar, J. Rayuela: 559.

58 Ibid.: 715-716.

59 Kopmacap X. Письма к издателю. С. 83. 
его вариантах, подобно тому, как скульптор несет ответственность за все ракурсы, под которыми будут фотографировать его скульптуру, за движение, их все связующее» ${ }^{60}$. Но ответственность должен нести и читатель: в произведении, достигшем «высшей подвижности», от его выбора, от каждого его шага будет зависеть то, что происходит в микрокосме книги, подобно тому, как зависит от него происходящее в реальности. Такое произведение - «зеркало человеческого удела» откроет человеку глаза на его собственную свободу. Эссе заканчивается словами: «Однажды, быть может, мы достигнем этого». Бютор реализует свой замысел в романе «6 810000 литров воды в секунду» (1965), но Кортасар опередил его на несколько лет «Игрой в классики». В полном соответствии с требованиями Бютора, он вырабатывает разные траектории чтения романа, предоставляя читателю самому выбрать свой путь - как в книге, так и в жизни: по мысли Аны Марии Барренечеа, два способа чтения соответствуют двум способам восприятия мира: поверхностному и глубинному, при котором открываются тайные связи всего со всем ${ }^{61}$.

\section{5. Текст/Метатекст}

«Мы живем в эпоху рефлексии» - писал Сартр в предисловии к «Портрету неизвестного» - и «роман занимается саморефлексией» ${ }^{62}$. Часто эта саморефлексия принимает форму геральдической конструкции (mise en abyme), ярким примером чего служат романы «Распределение времени» и «Изменение» Бютора. Бютор отмечал, что в современном искусстве исчезает жанровая граница между критическими и собственно художественными текстами: «Критика и творчество оказываются двумя видами одной и той же деятельности» ${ }^{63}$. Французский исследователь Марк Гонтар указывает на то, что метатекстуальную практику новороманистов необходимо отличать от метатекстуальной практики постмодернистов: «Особое выделение нарративной деятель-

60 Бютор М. Роман как исследование. С. 48. [Цитата приводится с небольшими изменениями - A.Г.]

61 Barrenechea, A.M. "La estructura de Rayuela." Litterae Hispanae et Lusitanae (1968): 74.

62 Сартр Ж-П. Ситуации. М.: Ладомир, 1998. С. 346.

63 Цит. по: Пьеге-Гро Н. Введение в теорию интертекстуальности. М.: ЛЕНАНД, 2015. С. 221. 
ности в произведениях... становится постмодернистским только тогда, когда воздерживается от любой онтологической или экзистенциальной интенции (от «смысла» письма!), чтобы развиваться в игровом или ироническом пространстве» ${ }^{64}$. У Бютора эти интенции явлены со всей полнотой.

Жак Ревель пишет о месяцах, проведенных в Блестоне, чтобы «расшифровать» коварный город; письмо - единственное оружие Жака против его пагубных чар: каждый вечер он выводит длинные цепочки предложений на белых листах бумаги, чтобы не дать грязи и туманам города себя ослепить. Белый лист - это «зеркало-ловушка» ${ }^{65}$, которое должно открыть Жаку его собственное лицо, а вместе с тем - лицо Блестона, и тогда они станут неотличимы друг от друга. После отъезда Жак хочет отдать написанное сестрам Бэйли, в которых он поочередно был влюблен, чтобы через них город начал «сам себя читать» и вместе с тем - выздоравливать.

В конце пути в Рим Леон Дельмон понимает, что он должен написать книгу (эту книгу и держит в руках читатель), которая станет его опорой и поможет заполнить обнаруженную им внутри себя «пустоту». Эта книга откроет путь к свободе, которую Леон тщетно искал в Сесиль: то был мираж, навеянный Римом. Невозможное в реальности сближение двух городов - Рима и Парижа - осуществится в тексте, в котором будет запечатлен решающий эпизод его жизни, «сдвиг», совершившийся в его сознании, а вместе с ним - образ Сесиль «во всей своей красоте, в ореоле римского величия» ${ }^{66}$.

Экзистенциальное значение метатекст имел и для Кортасара. В эссе «Об ощущении, что ты не совсем здесь» (“Del sentimiento de no estar del todo"), входящем в книгу-коллаж «Вокруг дня на 80 миpax» (La vuelta al día en ochenta mundos, 1967), он писал, что многие осуждают его романы за то, что он ведет в них интеллектуальный поиск самого романа. Но для него этот поиск - «магическая диалектика», и пока она длится, мужчина-ребенок, каковым он является, пытается завершить игру всей своей жизни: роман - это «игра на краю балкона»,

64 Гонтар M. Постмодернизм во Франции: определение, критерии, периодизация // Постмодернизм: парадоксы бытия. Ежегодник «Человек. Образ и сущность». М.: ИНИОН РАН, 2006. С. 164.

65 Butor, M. L'Emploi du temps. P.: Les Éditions de Minuit, 1957: 275.

66 Бютор М. Изменение. М.: Художественная литература, 1983. С. 233. 
«спичка, поднесенная к бутылке с бензином», «заряженный револьвер на ночном столике» ${ }^{67}$.

\section{6. Персонаж}

Одной из конституирующих черт «нового романа» является «развоплощение» персонажа: персонаж становится простым субъектом действия, взгляда, слова. У истоков теоретического осмысления этого процесса стоит эссе «Эра подозрения» (1950) Натали Саррот, в котором писательница среди прочего отмечала, что в современной литературе персонаж теряет свое былое, «бальзаковское», достояние: предков, имущество, одежду, тело, лицо, и главное - свой характер и свое имя. Вслед за Саррот Роб-Грийе отнес категорию персонажа к «устаревшим понятиям». Бютор говорил о том, что новороманисты показывают персонажа не «крупным планом», как то делал Бальзак, a «наискось» ${ }^{68}$ : персонаж лишается своей «архетипичности», в его характере не остается ничего «образцового».

Если в европейской литературе персонаж теряет свою былую значимость, то с известными оговорками можно сказать, что в литературе латиноамериканской, начиная с 1940-х гг., он только начинает ее обретать: изменение роли персонажа свидетельствовало о разрыве с регионалистской традицией и возникновении «нового» романа. В так называемом «романе земли» (романе теллурическом) конца XIX - начала XX в. главным героем была природа: сельва, льяносы, пампа; тогда как «новый» роман обращается к человеку, а вместе с тем - к проблемам философского и психологического порядка. Сравнивая французский «новый роман» и «новый роман» латиноамериканский, Х. Аласраки замечает: «В испаноамериканском романе персонаж все еще является центром, к которому стягивается повествование, из которого оно вырастает и в котором находит свое оправдание» ${ }^{69}$. Именно поэтому читатель «нового» латиноамериканского романа не теряет возможности отождествлять себя с героями. Так, Кортасар в интервью Арсу говорил, что в персонаже Оливейры он создал «человека с улицы, человека умного и образованного, но

67 Cortázar, J. La vuelta al dia en ochenta mundos: 21.

68 Butor, M. Curriculum vitae: entretiens avec André Clavel. P.: Plon, 1996: 103.

69 Alazraki, J. Hacia Cortázar: aproximaciones a su obra. Barcelona: Editorial Anthropos, 1994: 202. 
в то же время обычного и даже заурядного, чтобы читатель мог без труда отождествить себя с ним и даже превзойти его» ${ }^{70}$.

Примечательно, что в эссе «Положение романа», увидевшем свет всего лишь на полгода позже журнальной публикации «Эры подозрения» Саррот, Кортасар указывал на то, что в современном романе «уже нет персонажей» [курсив Кортасара - A.Г.]. Это заявление в духе «нового романа» получает, однако, не «новороманистское» продолжение. Если у новороманистов персонаж «развоплощается», то у Кортасара, напротив, он обретает плоть: в современном романе нет персонажей «...есть только сообщники. Будучи нашими сообщниками, а также свидетелями, они всходят на трибуну, чтобы - почти всегда - осудить нас; время от времени кто-то дает благосклонное свидетельство и помогает нам лучше понять сущность положения современного человека» ${ }^{71}$. Эту же мысль мы находим в 115 главе «Игры в классики», в одной из заметок Морелли: «Роман, который нас интересует, - не тот, что помещает своих персонажей в ситуацию, а тот, в котором ситуация - в самих персонажах, благодаря чему они перестают быть просто персонажами, а становятся личностями. Происходит нечто вроде экстраполяции, посредством которой они выскакивают к нам, или мы - к ним» ${ }^{72}$.

Можно сказать, что кортасаровский персонаж проходит эволюцию, обратную эволюции персонажа французского «нового романа». В ранних фантастических рассказах Кортасара персонажи, по его собственным словам, являются «марионетками» (pantins) фантастического действия. Все меняется в рассказе «Преследователь» (“El Perseguidor”, 1958): в нем не персонаж «вертится» вокруг рассказа, а рассказ - вокруг персонажа. Кортасар объяснял, что если в рассказах до «Преследователя» он мог частично пожертвовать «человечностью» (humanidad) персонажа, то в последующих он не смог бы этого сделать. Персонажи романа «Выигрыши» - это уже, по определению автора, персонажи «живые», «из плоти и крови» ${ }^{73}$.

Среди кортасаровских персонажей есть два, формально напоминающих персонажей «нового романа»: это «мой крестный» (mi paredro; в переводе Е. Лысенко - «мой сосед») в романе «62. Модель для сборки» и «тот самый, о котором я тебе говорил» в романе «Книга

70 Harss, L. Los nuestros. Buenos Aires: Editorial Sudamericana, 1966: 299.

71 Cortázar, J. Obra critica II: 224-225.

72 Cortázar, J. Rayuela: 657.

73 Bjurström, C.G. Entretien: 17. 
Мануэля» (el que te dije; в переводе Е. Лысенко - «мой друг, о котором я тебе говорил» в начале романа и просто «мой друг» в дальнейшем). «Мой крестный» - говорится в романе - было выражением, принятым в «зоне» (зона возникала тогда, когда друзья собирались вместе): одного из членов компании всегда называли «мой крестный», причем никто не знал наверняка, когда он является «крестным» других. Друзья приписывали ему некоторые свои слова и поступки, так как «крестный» был в некотором смысле воплощенной совестью «зоны», ее свидетелем, а главное - свидетелем Города. Но предоставляя ему слово, упоминая его в письмах и при встречах, герои начинали вести себя так, словно «крестный» живет собственной жизнью, существует где-то вне их самих - такое же впечатление складывается у читателя романа. «Мой крестный» появляется тогда, когда нам точно известно, что делают остальные персонажи и где они находятся.

«Тот самый, о котором я тебе говорил», - объяснял Кортасар Эвелине Пикон Гарфилд, - распространенное аргентинское выражение, употребляющееся в кругу друзей: так в шутку говорят в третьем лице о присутствующем ${ }^{74}$. Так же, как и «мой крестный», «тот самый, о котором я тебе говорил» наделен в романе «свидетельской» функцией - он выступает в роли хроникера Ходы. Можно сказать, что эти два безымянных кортасаровских персонажа иллюстрируют цитировавшееся выше утверждение: в современном романе нет персонажей, а есть «сообщники», «свидетели».

Персонажи Морелли в чем-то приближаются к персонажам «нового романа». В 124 главе «Игры в классики» говорится: «Легко можно было заметить почти что головокружительное обнищание мира его романов - это проявлялось не только в простоте, близкой к обезьяньей, его персонажей, но и в самих их поступках, а главное - в непоступках. В конце концов с ними вообще перестало что-либо происходить, они без конца обсуждали и высмеивали свою никчемность» ${ }^{75}$. Персонажи Морелли - «ученые обезьяны» - лишались своей «мифопоэтической силы» (ср. «архетипичность», о которой говорил Бютор), души, а вместе с тем - «ложной» человечности. Примечательно, что аргентинский романист Эрнесто Сабато, критикуя Роб-Грийе, сравнивал его персонажей именно с обезьянами.

\footnotetext{
74 Picón Garfield, E. Cortázar por Cortázar: 62.

75 Cortázar, J. Rayuela: 671.
} 


\section{7. Психологизм}

Кортасар говорил во многих интервью, что он всегда разделял стремление новороманистов освободить роман от психологических условностей: «Думаю, я всегда относился с симпатией к этой очень необходимой попытке упразднить психологический роман в духе Мориака [Кортасар имеет в виду Франсуа Мориака. - А.Г.], уже полностью исчерпавший себя» ${ }^{76}$. Поэтому часто, оценивая собственные романы, Кортасар сопоставлял их с «новым романом». Так, в интервью Омару Прего он сказал, что «Игра в классики» - «очень психологический роман», и в этом смысле у него нет ничего общего с «новым романом» ${ }^{77}$. О замысле «62. Модель для сборки» Кортасар писал Франсиско Порруа следующее: «После “Игры в классики”, как ты понимаешь, меня совершенно не интересует "психологический” роман, и я вовсе не настроен писать "nouveau roman", разве лишь в том смысле, что это тоже путешествие в незнаемые земли» ${ }^{78}$. Сходные мысли он выскажет шесть лет спустя, когда роман уже будет написан, отвечая Оскару Кольясосу: «В романе “62” я прощупывал почву, исследовал труднодоступные территории, пытаясь уйти от психологического романа, не прибегая к технике “нового романа” или “романа поведения”. Речь шла о том, чтобы посмотреть извне на группу людей, отчужденных друг от друга своими поступками и личными драмами... и в то же время изнутри (и это было главной целью книги) попытаться представить иное понимание каузальности (и случайности, которая, возможно, является скрытым проявлением последней, и разгадка которой подвела бы нас к миру с другой стороны)»79. Как видно из приведенных цитат, Кортасар во всех случаях подчеркивает, что его романы не имеют ничего общего с «новыми романами» - однако между его собственными теоретическими посылками и теоретическими установками новороманистов обнаруживаются многочисленные параллели.

\footnotetext{
76 Alazraki, J. Hacia Cortázar: aproximaciones a su obra: 202.

77 Prego, O. Fascinación de las palabras: 93.

78 Kopmacap X. Письма к издателю. С. 134. Ср. «Когда ты начинаешь писать книгу, перед тобой всегда открывается неизвестная область, которую необходимо исследовать, а для этого каждый раз требуется новый инструментарий» (Butor, M. Curriculum vitae: 104$)$.

79 Cortázar, J. "Literatura en la revolución y revolución en la literatura: algunos malentendidos a liquidar": 69.
} 
Позиция Кортасара в вопросе психологизма получает лаконичное выражение в одной из заметок Морелли (глава 97): «Отказаться от nсихологий [hacer psicologías - ненормативное множественное число привносит пейоративный оттенок $-A . \Gamma$.] и в то же время отважиться на попытку познакомить читателя - правда, определенного читателя, с миром личным, с личным жизненным опытом и размышлениями...» [курсив Кортасара - А.Г.] $]^{80}$. С одной стороны, «отказаться от психологий» значит отказаться от авторского анализа, от психологической диалектики: «Читатель лишится какого-либо моста, перемычки, причинной связи. Поступки, их последствия, разрывы, катастрофы, насмешка - просто как они есть» ${ }^{81}$. В 109 главе Кортасар подробнее объяснит свой творческий метод: книга в его представлении - это не фильм, а серия фотографий: связывать их, превращать в кинематографическую ленту - значит потакать читателю-самке. Незавершенность должна побуждать читателя рисковать, участвовать в судьбе персонажей: он должен сам выстроить «мостики между различными кусками этих довольно туманно представленных и слабо охарактеризованных жизней» ${ }^{82}$, предположить или придумать причины поступков героев. Об этом же говорил Роб-Грийе: в новом романе персонажей больше не будет сопровождать авторская интерпретация, но «сообразно интересам каждого читающего, они смогут дать простор любым комментариям» ${ }^{83}$. Как замечает Брюс Морриссетт: «Создавать, а не анализировать психологию персонажей - вот в чем состоит искусство Роб-Грийе» ${ }^{84}$.

С другой стороны, под «психологиями» Кортасар понимает, говоря словами Паулы из «Выигрышей», «своеобразный универсальный сборник инструкций», в соответствии с которым ведут себя персонажи будь то в индийском романе, будь то в американском бестселлере ${ }^{85}$. Так, поступки персонажей должны лишиться привычных психологических мотивировок. В тексте суперобложки первого издания «Игры в классики» мы читаем: «Персонажи “Игры в классики” идут навстречу собственному поражению с той иронией, в которой можно угадать их тайное торжество. На этой отуманенной территории, где они дви-

\footnotetext{
80 Cortázar, J. Rayuela: 607.

81 Ibid.: 607.

82 Kopmacap X. Игра в классики. С. 423.

83 Роб-Грийе А. Романески. С. 536.

84 Цит. по: La littérature en France depuis 1945. P.; Montréal: Bordas, 1970: 593.

85 Cortázar, J. Los premios. Madrid: Punto de lectura, 2007: 287.
} 
жутся, любовь, ревность и милосердие как бы дьявольски подчинены прямо противоположному знаку, и тут психологическая причинность в полной растерянности сдает свои позиции [курсив мой. - А.Г.], эти существа не подозревают, что с каждой новой фигурой их танца они все ближе и ближе к конечной мутации: это последний домик “классов", это - Иггдрасиль, самый центр Мандалы» ${ }^{86}$. Почти такими же словами Морелли излагает замысел так и не написанной им книги в 62 главе романа: «на этой территории психологическая причинность отступила бы в замешательстве» ${ }^{87}$.

Расставание Оливейры и Маги в 20 главе сложно назвать расставанием в привычном смысле слова. К этому и стремился Кортасар: «Я думаю, что мне удалось передать здесь то, что я не передал бы, если бы искал только патетическую сторону ситуации. Это была бы еще одна сцена расставания в ряду многочисленных сцен расставания, описанных в литературе» ${ }^{88}$. Та же идея выражена в одной из заметок Морелли: «Там, где должно было бы быть расставание - рисунок на стене; вместо крика - удочка; смерть сведется к трио для мандолин» ${ }^{89}$. Поведение Маги и Оливейры - своего рода рисунок на стене: они шутят, смеются, пьют матэ, и читатель не может понять, что происходит. А фоном смерти Рокамадура в 28 главе служит бесконечный разговор об абсурде, о том, правильным ли путем идет человечество, постоянный стук в потолок и перебранки со стариком-соседом сверху. Знаменитая «глава с доской» (41) является, по мнению Кортасара, одной из самых глубоких глав во всем романе, так как в ней «решаются судьбы персонажей». Но вместе с тем все в ней - «безудержная шутка» ${ }^{90}$. В романе «62. Модель для сборки» Телль, ревнуя Хуана к Элен, не находит ничего лучшего, чем послать ей куклу: как говорил Кортасар в интервью Омару Прего, он не хотел, чтобы поведение ревнующей героини соответствовало «типичному поведению ревнующей женщины, освещенному всей традицией французского психологического романа ${ }^{91}$.

\footnotetext{
86 Kopmacap X. Письма к издателю. С. 65.

87 Cortázar, J. Rayuela: 524.

88 Harss, L. Los nuestros: 284.

89 Cortázar, J. Rayuela: 607.

90 Harss, L. Los nuestros: 282.

91 Prego, O. Fascinación de las palabras: 93.
} 
В плане психологизма ближе всех к Кортасару оказывается Натали Саррот. Один из вопросов, которые журнал Tel Quel задал писательнице в письменном интервью 1962 г. из цикла «Литература сегодня», формулировался следующим образом: «По Вашему мнению, может ли роман быть не-психологическим? Или всякий роман в конечном счете оказывается психологическим?» Саррот отвечала, что все зависит от того, что понимать под психологией. Если психология - это «анализ чувств, определение мотивов наших действий, изучение характеров», тогда, по ее мнению, современный роман не только может не быть, но и не должен быть психологическим. Если же под психологией понимать «создание психического мира», тогда ее романы - исключительно психологические ${ }^{92}$. Воссоздание «мира личного», «личного жизненного опыта и размышлений» Морелли соотносится с «созданием психического мира», о котором говорит Саррот.

Осознав ограниченность традиционного психологизма, Саррот обращается к сфере естественных наук. Обосновывая свою концепцию тропизмов (этот реально существующий в биологии термин обозначает реакцию растений на внешние раздражители), писательница опирается на французского биохимика и микробиолога, лауреата Нобелевской премии, Жака Моно. Ученый утверждал, что на глубинном уровне не только ощущения, но и мысли не обладают словесной природой: когнитивные функции человека не связаны непосредственно с языком. Об этом же говорит Саррот: искомая ею универсальная психическая материя существует вне слов. Эта материя неизменна, на уровне тропизмов стираются все различия между людьми: между Жанной д’Арк и Гитлером, между белым европейцем и черным африканцем ${ }^{93}$. Поэтому, объясняла писательница в «Эре подозрения», в ее произведениях «рухнули непроницаемые перегородки, отделявшие персонажей друг от друга», персонаж «стал произвольной лимитацией, условной вырезкой на общей для всех ткани, которую каждый содержит в себе целиком» ${ }^{94}$.

Знаменательно, что, подобно Саррот, Морелли обращается к области естественных наук: альтернативу психологии («психология, само слово похоже на старуху») он находит в теории химической при-

\footnotetext{
92 Sarraute, N. Evres complètes: 1659.

93 Ibid.: 1807.

94 Цит. по: Косиков Г.К. Собрание сочинений. Т.2. М.: Центр книги Рудомино, 2012. C.165.
} 
роды ментальных процессов, разработанной шведским нейробиологом Хольгером Хиденом. Так же, как и Саррот, Морелли интересовала область надличного. В его замысел входило воплотить «безличную драму», выйдя за рамки социального: «За пределами социального поведения можно было бы предположить взаимодействие совсем иной природы... драма без Эдипа, без Растиньяка, без Федры, драма безличная постольку, поскольку сознание и страсти персонажей оказываются вовлеченными лишь а posteriori. Как если бы сублиминальные слои сами завязывали и развязывали клубок отношений между участниками драмы. Или как если бы - на радость шведу - некие индивидуумы, безо всякого намерения, включались бы в глубинные химические процессы других людей, и наоборот, и, таким образом, возникли бы чрезвычайно любопытные и будоражащие цепные реакции расщепления и преобразования» ${ }^{95}$.

Кортасар чувствовал близость осуществленного им в романе с тем, что в своих романах делала Саррот, но он прекрасно понимал, что именно его от Саррот - и от «нового романа» вообще - отличает. Когда Гонсалес Бермехо спросил писателя, не считает ли он, что роман «62. Модель для сборки» слишком «геометричен», он согласился с тем, что книга, возможно, получилась немного сухой, так как он очень хотел воплотить свою теорию «человеческого бильярда», но он стремился разрядить атмосферу с помощью юмористических эпизодов, в которых происходит своеобразная циркуляция воздуха: «В эпизодах, проникнутых юмором, не имеющих отношения к роману - эпизоды с участием моих двух соотечественников [Калака и Поланко. - А.Г.], история с кораблекрушением, передряги в Лондоне - я пытался избежать, насколько возможно, геометричности представления, чтобы все это не превратилось в один из “новых романов”, как, например, у Натали Саррот с ее тропизмами. То, что она сделала - замечательно, но это уже сделано, и незачем было делать это заново. В этом смысле я хотел, чтобы книга, которую я писал, была похожа на все остальные мои книги, с юмором и т.д.» ${ }^{96}$

Еще одно важное отличие заключается в следующем: если Саррот исследовала внутренний мир человека, то Кортасар стремился открыть силы, движущие человеком, вовне. Саррот искала «новую

\footnotetext{
95 Кортасар Х. Игра в классики. С. 337-338.

96 González Bermejo, E. Conversaciones con Cortázar: 95.
} 
реальность ${ }^{97}$ в плоскости чувств, в плане хоть и иррациональном, но «физическом», Кортасар же - в плане метафизическом.

\section{8. Сюжет}

В эссе «О нескольких устаревших понятиях» Роб-Грийе говорил о том, что уже начиная с Флобера интрига перестала составлять костяк повествования. Действительно, в одном из писем к Луизе Коле Флобер говорил о том, что мечтает написать книгу, у которой практически не было бы сюжета или, по крайней мере, сюжет которой был бы почти незаметен - книгу «ни о чем», и книгу «из ничего», которая держалась бы только силой своего стиля, подобно тому как Земля сама собой держится в воздухе. Спустя век именно «ничто» станет основополагающей категорией новой литературы: «Мы ничего не знаем, и мы не знаем ничего, так как нечего знать. Лишенная знания, литература ныне стала литературой незнания, невозможной литературой, ищущей лишь свою собственную возможность, себя самое как свой единственный сюжет... Нечего знать, нечего сказать: можно лишь говорить ничто...» ${ }^{98}$, - такое заключение делалось в февральском номере журнала Les Lettres nouvelles за 1963 г. В интервью 1965 г. Натали Саррот скажет почти что флоберовскими словами, что мечтает о «книгах ни о чем, почти без сюжета, освобожденных от персонажей, от интриги и всех устаревших аксессуаров, сведенных к чистому движению, сближающему с абстрактным искусством» ${ }^{99}$. По мнению писательницы, сюжет, как и персонажи, лишь отвлекает внимание читателя от того, что составляет суть ее произведений - от тропизмов: его функция должна сводиться к тому, чтобы быть «тонкой нитью», которая позволит расположить психологические движения вокруг определенных тем и не даст им распасться ${ }^{100}$.

С одной стороны, сюжет в «новом романе» колеблется на грани бессюжетности, «ничто», с другой стороны, как замечает Роб-Грийе, «было бы ошибкой утверждать, что в современных романах больше ничего не происходит... Исчезает не история, а ее несомненный, спо-

\footnotetext{
97 Sarraute, N. Evres complètes: 1675.

98 Андреев Л.Г. Современная литература Франции. 60-е гг. С. 7.

99 Цит. по: Там же. С.19.

100 Sarraute, N. Evres complètes: 1818.
} 
койный, простодушно-невинный характер» ${ }^{101}$. С утратой веры в универсальную логику всего сущего, в «устойчивый, непротиворечивый, непрерывный, однозначный, полностью поддающийся расшифровке» ${ }^{102}$ мир нельзя продолжать писать так, как писали в первой половине XIX в. В «новых романах» перестают действовать привычные причинно-следственные связи, логика повествования нарушается, так как стирается граница между тем, что происходит в реальности, и тем, что происходит в сознании и воображении персонажей. Развитие сюжета осложняется многочисленными повторами: создается впечатление, что действие движется не вперед, а вспять, немного отклоняясь от пройденного пути, так как повторение никогда не бывает «чистым» - оно несет в себе определенную вариацию. Чтение подобного текста превращается в своего рода расследование - не случайно новороманистов привлекали детективные сюжеты. Примечательно, что уже в 1947 г., за 6 лет до публикации романа «Ластики» Роб-Грийе, Сартр в предисловии к роману «Портрет неизвестного» Саррот охарактеризовал его как «антироман, который читается, как детектив» ${ }^{103}$.

Как и новороманисты, Кортасар всегда стремился выйти за рамки традиционного линейного, логически выстроенного повествования. В статье «Литература в революции и революция в литературе» мы находим следующую мысль, созвучную заявлениям Роб-Грийе: «Литература, стремящаяся проникнуть на новые территории [...] не может больше существовать в рамках старой романной формулы рассказывания истории, она должна сама создать свою структуру и определить ход своего развития» ${ }^{104}$. В основе кортасаровской повествовательной структуры лежит то, что сам он называет «элементом»: «Я чувствую, что следует фиксировать элементы. Этой цели служит поэзия, а также некоторые ситуации в романах, рассказах или пьесах. Все остальное же сводится к заполнению, а это у меня получается плохо», - признается Морелли в 94 главе «Игры в классики». В силу того, что промежутки между «элементами» остаются незаполненными, в романах Кортасара нет присущей традиционному роману «когерентности»: между

101 Роб-Грийе А. Романески. С. 542.

102 Robbe-Grillet, A. Pour un nouveau roman. P.: Minuit, 1963: 31.

103 Sartre, J.-P. "Préface." Sarraute, N. Portrait d'un inconnu. P.: Gallimard, 1956: 8.

104 Cortázar, J. "Literatura en la revolución y revolución en la literatura: algunos malentendidos a liquidar": 73 . 
частями целого устанавливаются не каузальные, а «поэтические», ассоциативные связи.

В 109 главе «Игры в классики» мы читаем: «Книга должна была походить на картинки гештальт-психологов, где некоторые линии побуждали бы человека, на них смотрящего, провести в воображении те, которых недостает для завершения фигуры. Однако случалось, что недостающие линии бывали как раз наиболее важными и теми единственными, которые следовало принимать во внимание» ${ }^{105}-$ здесь Кортасар словно описывает прием паралипса, широко применяемый как им самим, так и новороманистами. Так, например, в «Игре в классики» остается неизвестным, что случилось с Магой и покончил ли с собой Оливейра. В «Соглядатае» Роб-Грийе мы так и не узнаем, что произошло в пропущенный в повествовании час: действительно ли Матьяс совершил убийство, или он просто стал его свидетелем, а, может быть, услышав о преступлении, вообразил себя «действующим лицом»? ${ }^{106} \mathrm{~B}$ «Распределении времени» ни одна из детективных завязок не получает развития.

С Натали Саррот Кортасара сближает то, что в его романах практически нет описаний, а место событий занимает диалог. Когда Морелли говорит о том, что современный роман «утрачивает описание» ${ }^{107}$, эта характеристика явно не относится к романам Роб-Грийе и Бютора, но она вполне справедлива по отношению к романам Саррот. Сам Кортасар указывал на то, что персонажи его романов мало что делают и почти не перемещаются: их действие - это разговор. Как замечает известный пуэрториканский литературовед Мария Тереса Бабин, прочитав «Игру в классики», многие с трудом ответят на вопрос, что происходит в романе ${ }^{108}$. Однако именно в диалогах раскрываются все заложенные Кортасаром в текст смыслы. В романах же Саррот диалог играет служебную роль: диалог представляет интерес только в той мере, в какой он помогает выявиться неуловимым психическим движениям.

Между тем многие эпизоды в романе «занимательны» в традиционном понимании, в них есть интрига, читателю интересно узнать,

105 Кортасар X. Игра в классики. С.423.

106 Зонина Л.А. Тропы времени: заметки об исканиях французских романистов (60-70-е гг.). М.: Художественная литература, 1984. С. 112.

107 Cortázar, J. Rayuela: 657.

108 Babín, M.T. "La antinovela en Hispanoamérica.” Revista Hispánica Moderna 3/4 (Jul.-Oct. 1968): 528. 
«чем все закончится»: таковы эпизод смерти Рокамадура в 28 главе, «эпизод с доской» в 41, глава 56, в которой Оливейра готов выброситься из окна. Кортасар жаловался в одном письме к Порруа, что хрестоматийной в «Игре в классики» стала 23 глава - концерт Берт Трепа - хотя в ней в наименьшей степени проявляется антироманный пафос книги. Чем объяснить сосуществование «романных» и «антироманных» глав, если, по-видимому, Кортасар придавал бо́льшее значение последним?

Интересное объяснение этому дает уругвайский критик и публицист Эмир Родригес Монегаль. Во время беседы с Эрнесто Сабато, в которой участвовал также эмигрировавший во Францию кубинский писатель Северо Сардуй, Родригес Монегаль вкратце изложил свою концепцию «диалектики романа». В литературе всегда сосуществуют две линии: «романный роман», или «роман-роман», и «роман, критикующий роман» - примером чего служат рыцарские романы и «Дон Кихот», «История Тома Джонса» Филдинга и «Жизнь и мнения Тристрама Шенди» Стерна. Обе модели выявляются и в современном латиноамериканском романе. Линия «романа-романа» представлена «Веком Просвещения» А. Карпентьера, «О героях и могилах» Э. Сабато и «Зеленым домом» М. Варгаса Льосы. Линию же «романа, критикующего роман», которую Родригес Монегаль называет также линией «антиромана», или “nouveau roman”, представляют такие писатели, как Кортасар, Фуэнтес и Сардуй. «Роман, критикующий роман» сохраняет связь с «романом-романом», так как помимо критики в нем есть также повествовательные элементы, и это особенно заметно в наиболее экспериментальных текстах: «В определенный момент автор словно говорит себе: ладно, довольно теории, позволим себе удовольствие и будем рассказывать» ${ }^{109}$.

Кортасар говорил, что в романе «62. Модель для сборки» его целью было «написать книгу, которая, в противоположность романам новороманистов, была бы насыщена действием, которая бы имела завязку и развязку, особенно развязку» ${ }^{110}$. С событийной точки зрения развязкой романа становится убийство Элен, но тот факт, что происходит оно в плане ирреальном - в пространстве Города - лишает финал безусловности.

Детективные элементы в сюжете романа сближают его с французским «новым романом». Так, Хуан и Телль следят за каждым шагом

109 "Por una novela novelesca y metafísica." Mundo Nuevo 5 (Nov. 1966 ): 12-13.

110 Prego, O. Fascinación de las palabras: 93. 
фрау Марты, пытаясь выяснить, кто она и зачем завязала знакомство с туристкой-англичанкой. Настоящая криминальная история - это дело месье Окса, прятавшего в набивку кукол разные предметы, о некоторых из которых читатель так ничего и не узнает. Одна из этих кукол попадет к Элен, и она пронесет ее через весь роман в загадочном свертке, перевязанном желтой тесемкой, который ей надо передать кому-то, кого она не знает, в отеле Города. В ее истории словно повторяется история солдата из романа «В лабиринте» Роб-Грийе. Сходство усиливается за счет того, что оба героя (быть может) в конце умирают. Примечательно, что в тот миг, когда Хуан понимает, что в свертке лежала кукла, он говорит себе, что бесполезно воображать, будто в нем лежит что-то другое: портативный набор для анестезии, образцы лекарств, пара туфель. Мотив коробки из-под туфель возникает в тексте и раньше: когда Хуан и Телль ехали в поезде и Хуан рассказывал ей о месье Оксе, к ним в купе зашла рыжая женщина, из сумки которой выглядывала коробка, похожая на обувную - впоследствии оказалось, что в ней лежала не обувь, а кукла.

Словно пародируя излюбленный новороманистами прием повтора, Кортасар трижды повторяет последний разговор Хуан и Элен в поезде: Хуан пытается заговорить с Элен о прошлой ночи, подробное описание которой дается между повторяющимися фрагментами текста, но разговор каждый раз обрывается на фразе: «Элен, Элен, прошлой ночью...» ${ }^{111}$ Интересно, что в «Игре в классики» Кортасар не допустил одного возникшего в конце работы повтора: переписывая текст на чистовик, он обнаружил, что первая написанная им глава невероятно напоминает последнюю, в которой Оливейра строит оборонительные сооружения из ниток и тазов с водой против Тревелера, и тогда, чувствуя себя немного виноватым, он вытащил этот «камень, лежавший в основании всего здания», но оно не рухнуло.

Характеристика, которую дает «новому» латиноамериканскому роману Иван Шульман, в полной мере приложима и к роману французскому, в обоих случаях мы попадаем в мир «алогичный, наполненный тревогой, жестокий и ироничный» ${ }^{112}$. Не случайно одним из важнейших мотивов в «новом романе» становится «трещина» как знак скрытой дисгармонии. В комнате, которая описывается в романе «В лабирин-

111 Cortázar, J. 62/Modelo para armar. México: Punto de lectura, 2013: 301, 311, 312.

112 Schulman, I. "La novela hispanoamericana y la nueva técnica." Coloquio sobre la novela hispanoamericana. México: Fondo de Cultura Económica, 1967: 23. 
те», под потолком, в самом углу, есть едва заметная темная черточка: несколько раз по ходу повествования у кого-то возникает желание подняться и взглянуть на нее поближе: действительно ли это трещина, а может быть - запылившаяся паутинка или дефект штукатурки? Однако у того, кто об этом думал, не хватило времени: загадка (один из эпитетов трещинки - «загадочная») так и остается неразгаданной. В «Распределении времени» Бютора повторное приглашение на обед в доме у Дженкинса, одного из сослуживцев Жака Ревеля, стало для него свидетельством того, что ему удалось проникнуть в «тонкую трещину» (fêlure) «стены из мутного стекла» ${ }^{113}$, отделяющей его от Блестона. В конце романа эта трещина материализуется: в один из последних дней в городе Ревель видит «щель» (rainure) между двумя кирпичами в стене - «приоткрытый глаз» города - и «приникает» к ней взглядом, пьет ее зелье - смесь слез и яда - «эликсир бессмертия», словно приобщаясь к сущности города, позволяя ему войти в себя ${ }^{114}$. В «Игре в классики» образ трещины появляется в следующем контексте: в 98 главе Оливейра, тоскуя по потерянной Маге, думает, что она никогда не узнает о том, что ее палец указывал на «тоненькую трещинку, раскалывающую зеркало» ${ }^{115}$. В этой трещинке приоткрывается другая реальность - реальность, доступная Маге, но не доступная Оливейре.

\section{9. Пространственно-временная организация текста}

Ролан Барт в эссе «Объективная литература» ("Littérature objective", 1954) указывал на то, что пространство в романах РобГрийе «де-евклидизируется» ${ }^{116}$ : в то время как наблюдатель остается неподвижен, «пространственное поле» вокруг него движется, что создает кинематографический эффект. Цель Роб-Грийе - «рассеять» субстанцию: чрезмерная подробность описаний ведет к тому, что предмет «тонет» в линиях и непрестанно умножающихся планах, вследствие чего разрушается его цельность.

В произведениях Бютора пространство также «де-евклидизируется». Бютор считал, что пространство, в котором мы живем, не

113 Butor, M. L'Emploi du temps: 52.

114 Ibid.: 297.

115 Cortázar, J. Rayuela: 609.

116 Barthes, R. Essais critiques. P.: Éditions du Seuil, 1964: 34. 
является ни в коей мере евклидовым, один элемент которого исключает другие, так как в каждой точке пространства содержатся другие пространства. Это объясняется тем, что помимо пространства физического - улицы, города, страны - существует пространство информационное. Так, в любом городе присутствуют многие города: о них говорится в учебниках географии, в газетах, их показывают в кино, они описываются в книгах. Яркой иллюстрацией этого положения является роман «Изменение», где многообразные связи устанавливаются между Парижем и Римом: так, например, и в Париже и в Риме есть свой Пантеон; Леон, находясь в Риме, идет смотреть французский фильм и во второй раз встречает Сесиль; в комнате Сесиль висят парижские фотографии («с того места, где ты стоял, можно было глядеться, как в зеркало [курсив мой - A.Г.], в стекла парижских видов над кроватью» ${ }^{117}$ ), на одной из которых запечатлена Триумфальная арка - такая же фотография висит над головой Леона в поезде. Мотив соприсутствия городов есть и в романе «Распределение времени» - в Блестоне повсюду заявляет о себе прекрасный в глазах Жака Ревеля остров Крит: о нем показывают документальный фильм в кино; гордость городского музея - 18 гобеленов, изображающих разные эпизоды из жизни Тесея, в том числе убийство Минотавра. Можно сказать, что у Бютора так же, как и у Роб-Грийе, имеет место «умножение планов», но происходит оно не на текстовом, а на концептуальном уровне.

Кортасаровские миры подвергаются еще более глубокой «де-евклидизации». Писатель часто признавался, что его восприятие реальности не отвечает законам аристотелевской логики и евклидовым законам пространства: «В каком-то смысле я нахожусь в постоянной размолвке с пространством и временем» ${ }^{118}$.

К 60-м годам разного рода нарушения пространственно-временного континуума в литературе стали, на взгляд Кортасара, чем-то тривиальным. В произведениях Морелли вполне могло так случиться (хотя на деле этого не происходило), что через пять минут после битвы при Акциуме произойдет аншлюс Австрии, а человек, позвонивший в дверь на улице Кочабамба в Буэнос-Айресе, переступив порог, окажется во дворе дома Менандра в Помпеях. Но члены Клуба понимали, что сами по себе эти несоответствия не имеют значения - все это было «подстрекательством», «иносказанием», за которым лежал

117 Бютор М. Изменение. М.: Художественная литература, 1983. С. 124.

118 Bjurström, C.G. Entretien: 11-12. 
более глубокий и трудный смысл. У Кортасара этот смысл во многом определяется «теорией фигур».

Фигуры образуют не только явления неодушевленные, но и человеческие судьбы, жизненные ситуации: Кортасар говорил, что фигуры являются в некотором роде кульминацией мотива двойничества ${ }^{119}$. Человек не подозревает о том, что где-то в другом времени и пространстве у него есть или был двойник, жизнь которого неразрывно связана с его собственной. Богатая аргентинка Алина Рейес в рассказе «Далекая» (“Lejana”) чувствует боль и страдания жалкой нищенки в Бухаресте: разливая чай гостям или танцуя с женихом, она в то же время идет по замерзшему мосту, и снег забивается в ее дырявые ботинки. Пьер, герой рассказа «Тайное оружие» (“Las armas secretas”), повторяет преступление, совершенное в прошлом немцем-фашистом, помимо своей воли становясь орудием его мести в настоящем. В рассказе «Все огни огонь» (“Todos los fuegos, el fuego") в современности вновь разыгрывается драма неверности и возмездия, имевшая место много веков назад в одной древнеримской провинции. В роли изменника теперь выступает не женщина (Ирене, жена проконсула), а мужчина (Ролан), при этом измена, совершенная в мыслях, осуществляется в действительности. В огне, охватившем цирк, материализуется желание Ирене отомстить мужу, по вине которого погиб любимый ею гладиатор Марко. В современности карающий огонь охватывает квартиру Ролана, настигая спящих любовников в постели. В начале рассказа переход от одного временного и событийного плана к другому маркируется делением на абзацы, но по ходу развития действия эта граница стирается. Чем ближе развязка драмы («все огни - огонь»), тем сильнее выявляется связь прошлого и настоящего, тем напряжённее их взаимодействие: «“Яд, - думает Ирена, - когда-нибудь я найду яд, но теперь приму от него чашу с вином, будь сильней его, жди своего часа". Пауза удлиняется, как удлиняется коварная черная галерея, в которой отрывисто звучит далекий голос, повторяющий цифры»; «Ликас смеется и приветствует друзей, ожидая, когда проконсул двинется к выходу, после последнего приветственного жеста, но тот не торопится, словно ему приятно смотреть на арену, где подцепляют на крюки и уволакивают трупы. “Я так счастлива”, - говорит Соня, прижимаясь щекой к груди полусонного Ролана»; «“Мы не сможем выйти, - говорит она. - Они столпились внизу, как животные”. Тут Соня вскрикивает, стараясь

119 Harss, L. Los nuestros: 292. 
высвободиться из пламенного объятия, обжигающего ее во сне, и ее первый крик смешивается с криком Ролана, который тщетно пытается подняться, задыхаясь в черном дыму» ${ }^{120}$. Как видно из этих примеров, предложения соединены не механически: Ирене ждет часа мести Жанна ждет ответа Ролана; проконсул упивается видом поверженного соперника; Соня - своим превосходством над Жанной; и, наконец, пути к спасению нет ни в прошлом, ни в настоящем. Таким образом, на стыке двух планов особенно отчетливо выявляется «фигура», соединяющая персонажей вопреки времени и пространству.

В «Игре в классики» нарушение законов времени и пространства также связано с мотивом двойничества: Оливейра видит в Талите Магу, поэтому, как говорит Тревелер, у него «совершенно не по-евклидовски» смешиваются «реальность и воспоминания» ${ }^{121}$. То же самое имеет место в романе «62. Модель для сборки»: фрау Марта выступает в роли двойника «кровавой» венгерской графини Эржебет Батори; Элен видит в Хуане умершего у нее на глазах на операционном столе юношу.

Говоря словами Роб-Грийе, в «62. Модель для сборки» «пространство уничтожает время, а время разрушает пространство» ${ }^{122}$, так как Кортасар стремился передать одновременность происходящих в разных городах (в том числе и в Городе) событий. Как говорил писатель в интервью О. Прего: «Когда я начал писать “62” - со всем его антипсихологизмом, отказом от модели психологически мотивированного поведения нормальных людей - Город вполне логично представился мне как, скажем, своего рода место случайных встреч персонажей, вопреки всем человеческим и божественным законам» ${ }^{123}$.

Установить точную хронологию событий в романе не представляется возможным, так как «диахрония, временная последовательность не соответствуют самой природе рассказываемого» ${ }^{124}$. Но в этом «вязком», по выражению Х. Аласраки, времени, есть две точные даты: Хуан приходит в ресторан «Полидор» в канун Рождества,

120 Kopmacap X. Игра в классики. Рассказы. М.: НФ «Пушкинская библиотека»-AСТ, 2003. С. 798, 802, 803. Заметим, что в переводе В. Спасской во второй из приведенных цитат перед словами Сони «Я так счастлива...» добавлен абзацный перенос, которого нет в оригинале.

121 Cortázar, J. Rayuela: 500.

122 Robbe-Grillet, A. Pour un nouveau roman: 133.

123 Prego, O. Fascinación de las palabras: 95.

124 Cortázar, J. Último round. México: Siglo XXI Editores, 1969: 106. 
24 декабря (по-видимому, Кортасар любил эту дату, если изначально она фигурировала и в «Игре в классики» ${ }^{125}$ ); Элен совращает Селию во вторник, 17 июня. Как и в романе «Ластики», время в «62» можно назвать, пользуясь определением Р. Барта, «зеркальным временем». Прошлое и будущее движутся навстречу друг другу, подобно голосу и отражению толстяка-клиента в ресторане, встречаясь на поверхности мгновения-зеркала: в тот миг, когда фрау Марта проникает в номер молоденькой англичанки, Элен овладевает Селией.

Для Роб-Грийе запутанность хронологии - атрибут письма, текста. Было бы абсурдно полагать - пишет он - что в романе «Ревность» имеется «ясный и однозначный порядок событий, который не является порядком фраз в книге [...] Это был не запутанный рассказ о простой, внешней по отношению к нему истории, а опять-таки само развитие истории, не имевшей другой реальности, кроме реальности повествования〉 ${ }^{126}$. Совершенно иначе - у Кортасара. Писатель чувствовал, что сквозь многочисленные пространственные и временные зазоры в романе проглядывает другая реальность, та самая реальность, о которой говорится в 61 строфе классического тантрического текста «Виджняна Бхайрава Тантра»: «В тот миг, когда ты воспринимаешь два разных предмета и сознаешь, что между ними есть промежуток, уйди в этот промежуток. Если оба предмета одновременно скроются, в промежутке воссияет Реальность» ${ }^{127}$.

На первый взгляд, между кортасаровской картиной мира и картиной мира Бютора обнаруживается значительное сходство: разнообразные культурные и психологические параллели ведут к «встрече» ${ }^{128}$ удаленных друг от друга пространств и времен, их вза-

125 Время в «Игре в классики» обозначено условно как «1950-е». Изучая черновики романа, перуанский исследователь Хулио Ортега обнаружил, что Кортасар добивался этого сознательно: изначально действие романа было отнесено к 1952 г. Точную дату «в этот четверг, 24 декабря» в 1 главе Кортасар заменил на «в этот декабрьский четверг».

126 Роб-Грийе А. Романески. С. 598.

127 Cortázar, J. Último round: 108-109.

128 Во время интервью с Кортасаром Эвелин Пикон Гарфилд поделилась с ним одним своим наблюдением: по своему построению рассказ «Все огни огонь» очень напоминает эпизод романа «Распределение времени», в котором в тот самый момент, когда Жак Ревель смотрел документальный фильм про сгоревший древнеримский город, в Блестоне начался пожар. Исследовательница охарактеризовала происходящее в обоих случаях как «встречу», с чем Кортасар согласился: «Да, конечно, да. Это в некоторой степени одно и то же». (Picón Garfield, E. Cortázar por Cortázar: 82-83.) 
имоотражению. Но кортасаровская реальность имеет более глубокое метафизическое измерение. Так, жизнь героя рассказа «Другое небо» ("El otro cielo", 1966) - обыкновенного служащего буэнос-айресской биржи - так же, как и жизнь Леона Дельмона, протекает между двумя городами: Парижем и Буэнос-Айресом, с каждым из которых связана своя женщина (в первом - проститутка Жозиан, во втором - невеста Ирма). Но если у Бютора города разделены только географически, у Кортасара они разделены хронологически: прогуливаясь по галерее Гуэмес в Буэнос-Айресе середины XX в., рассказчик незаметно для себя оказывается в Галери Вивьен в Париже накануне франко-прусской войны. Фантастический переход из одного пространства в другое - не сон и не игра воображения, он по-кортасаровски реален.

\section{0. Положение читателя. Функция литературы}

Порывая с традициями письма, новороманисты порывают и с традициями чтения. Если раньше читатель получал «в готовом виде законченный, полный, замкнутый в себе самом мир», то теперь писателю необходимо читательское содействие - «содействие активное, сознательное, творческое [курсив автора - А.Г.]» ${ }^{129}$. В конце цитируемого эссе Роб-Грийе формулирует мысль, близкую Кортасару: участвуя в творческом процессе, читатель создает не только книгу, но и мир, а значит, он учится изобретать собственную жизнь.

Кортасар вкладывает в уста Моррели следующее признание: настоящий и единственный персонаж, который его интересует, - это читатель, в той мере, в какой хоть что-то из написанного им «могло бы изменить его, сдвинуть с места, удивить, вывести из себя» ${ }^{130}$. Он борется с «читателем-самкой» и мечтает о «читателе-сообщнике», который, говоря словами Натали Саррот, окажется «там же, где и автор, на глубине» ${ }^{131}$ : он будет переживать тот же опыт, что и писатель, «в тот же самый момент и в той же самой форме» ${ }^{132}$, и, возможно, то, что писатель обрел для себя, повторится, произведя намного больший эффект, в читателе. Роман будет для него неоформленной «глиной значений»,

\footnotetext{
129 Роб-Грийе А. Романески. С. 599.

130 Kopmacap X. Игра в классики. С. 396.

131 Cаррот H. Тропизмы. Эра подозрения. С. 211.

132 Cortázar, J. Rayuela: 560.
} 
фасадом здания, за окнами и дверьми которого творится тайна, - и читатель должен будет эту тайну искать: за тривиальными событиями он почувствует нечто намного более важное. «Читатель-самка» же останется по эту сторону красивого фасада: покончив с ним, писатель окажет содействие всем тем, кто так или иначе стремится достичь «другого», того, что находится «там, дальше» (все эти смыслы заложены в английском слове “yonder", которое использует Кортасар).

Читателя-сообщника искал также и Бютор: «Если романист выпускает в свет свою книгу, плод его главной жизненной деятельности, ему непременно нужен читатель, которому бы он указывал правильный путь, который бы участвовал (comme complice) в становлении и росте книги и был бы ее опорой, как личность, разум и взгляд» ${ }^{133}$. Произведения тех писателей, которые не требуют от читателя никаких усилий, не заставляют его возвращаться к самому себе, подвергать сомнению прописные истины, являются не чем иным, как ядом - писал Бютор в эссе «Роман как исследование».

С одной стороны, новороманисты выступали адептами «искусства ради искусства», отстаивая свое право на свободное творчество: «единственная возможная ангажированность для писателя, - заявлял Роб-Грийе, - это литература» ${ }^{134}$. Как замечала Натали Саррот, легко ответить читателям, которые спрашивают у писателей: может ли то, что вы пишете, помочь нам жить, узнать себя, измениться? Ответ: да, все это можно вывести из произведения, но тогда оно теряет свою настоящую ценность: эстетическую. Все это - «субпродукты» искусства, а не «продукты» ${ }^{135}$.

Вместе с тем новороманисты верят в «жизненную» функцию творчества, в то, что оно способно преобразовать действительность. Так, Роб-Грийе называл новороманистами всех тех, кто «решил заново изобрести роман, а значит - заново изобрести человека» ${ }^{136}$. В его представлении, создаваемые художником формы способны привнести «смыслы» в наш мир. Бютор говорил, что все великие произведения «изменяют способ нашего видения и описания мира, а следовательно,

133 Butor, M. Essais sur le roman: 17.

134 Роб-Грийе А. Романески. С. 592.

135 Sarraute, N. Evres complètes: 1692.

136 Robbe-Grillet, A. Pour un nouveau roman: 9. 
и сам мир» ${ }^{137}$ - в этом, по его мнению, состоит ангажированность писателя, и она требует «всех возможных усилий» с его стороны.

Еще большее значение «неэстетической» функции искусства придавал Кортасар, хотя пришел он к этому не сразу. Эволюцию взглядов Кортасара на цели творчества лучше всего выражает ставшая хрестоматийной фраза из статьи-письма к редактору кубинского журнала Casa de las Américas Роберто Фернандесу Ретамару «О положении интеллигента в Латинской Америке» (“Acerca de la situación del intelectual latinoamericano”, 1967): «Из Аргентины отбыл писатель, для которого венцом действительности, как это представлял себе Малларме, должна была стать Книга, а в Париже родился человек, для которого венцом писательства должна была стать действительность» ${ }^{138}$.

В творчестве Кортасара был свой этап «чистого искусства». В интервью Quinzaine littéraire он рассказывал, что для писателей его поколения и поколения Борхеса фантастический рассказ был формой эскапизма, своего рода «башней из слоновой кости»: все рассказы из сборника «Бестиарий» (1951), например, были созданы во времена диктатуры Перона. Все меняется с переездом в Париж. Именно в Париже Кортасар пишет рассказ «Преследователь» (1958), открывающий новый этап в его творчестве, который можно было бы называть в широком смысле «ангажированным». По словам писателя, в «Преследователе» он напрямую обращается к проблеме человека, открывает «ближнего». Кортасар признавался, что без этого рассказа он бы не написал «Игру в классики»: Оливейра продолжает поиск абсолюта, начатый джазовым музыкантом Джонни Картером.

Кортасар писал Франсиско Порруа об «Игре в классики»: «В конечном счете, я считаю, что надо сделать упор на аксиологических acnектаx [курсив мой - A.Г.] книги. Здесь я имею в виду последовательное и яростное изобличение неаутентичности человеческого бытия (например, монолог Оливейры в главе 48), а также (наиважнейшая вещь для Аргентины!) иронию, насмешку, издевку, всякий раз, когда автор или персонажи соскальзывают в философскую “серьезность"»" ${ }^{139}$. Эта мысль неоднократно повторяется в самом романе. Члены Клуба Змеи отмечают, что творчество Морелли характеризуется определенным

137 Бютор М. Роман как исследование. С. 40.

138 Кортасар X. О положении интеллигента в Латинской Америке // Писатели Латинской Америки о литературе. М.: Радуга, 1982. С. 286.

139 Kopmacap X. Письма к издателю. С. 39-40. 
противоречием: он выбирает повествовательную форму для «целей, которые, судя по всему, не были повествовательными» ${ }^{140}$. Когда в 141 главе «Игры в классики» говорится, что в задачи Морелли не входило создание теории, имеется в виду не только литературная программа, но и определенная жизненная философия: «По-видимому, в его задачи не входило создание теории, он не был силен в интеллектуальной рефлексии, но из всего им написанного явствовало куда более отчетливо, чем из какого-нибудь теоретического изложения или анализа, сколь глубоко прогнил мир, неподлинность которого он изобличал [курсив мой $-A . \Gamma.] \gg^{141}$.

Кортасар и новороманисты сходятся в стремлении к непосредственности, в желании освободить человека от гнета условностей. Кортасар поддержал бы следующее заявление Роб-Грийе: «Мы не верим больше в готовые, застывшие смыслы, которыми снабжал человека старый божественный порядок, и, вслед за ним, рационалистический порядок XIX века» ${ }^{142}$. По признанию Саррот, в своих текстах она стремится «подорвать» психологические, социальные, моральные категории, готовые определения. Современная литература, как и все другие виды искусства, пытается «выделить ощущение в чистом виде, сохранить прямой контакт с реальностью, из которой оно рождается, отказавшись от тяжелых, косных форм, его подавляющих» ${ }^{143}$. К этой непосредственности стремился и Кортасар: его целью было «дерзко вступить в контакт с реальностью без посредничества мифов, религий, систем и разграничений» ${ }^{144}$.

\section{1. Гуманизм и метафизика}

В 1963 г. в интервью парижскому еженедельнику Arts Кортасар признался: «Во всем, что я пишу, есть, я думаю, особое стремление: открыть новую этику и новую метафизику» ${ }^{145}$. Это утверждение дает своеобразный ключ к кортасаровской поэтике. Поиск новой этики не-

\footnotetext{
140 Cortázar, J. Rayuela: 600.

141 Ibid.: 716-717.

142 Роб-Грийе А. Романески. С. 592.

143 Sarraute, N. Evvres complètes: 1673.

144 Кортасар Х. Игра в классики. С. 439.

145 Kalda, A. "Julio Cortázar et Monteforte Toledo: les deux tendances de la littérature ibéro-américaine.” Arts 922 (1963): 2.
} 
разрывно связан с поиском «нового человека», с проблемой гуманизма, а поиск новой метафизики - с поиском новой реальности.

Проблема человека всегда стояла в центре внимания Кортасара, свидетельство чему - его отзыв об исследовании аргентинского антрополога Нестора Гарсиа Канклини, рассматривавшего все кортасаровское творчество в целом как «поэтическую антропологию»: «Мне также кажется, что, начиная с “Королей”, моей единственной темой (темой с многочисленными вариациями, как у Бетховена), выражавшейся с большим или меньшим успехом, была онтологическая загадка, предназначение человека, исследовать и понять которое невозможно, если одновременно не задаваться вопросом о человеческой сущности» ${ }^{146}$. Литература, по мнению Кортасара, должна содействовать «антропофании» - «явлению человека», нового человека, свободного от гнета западного рационализма, иудео-христианской догматики, старой этики и старой метафизики. Морелли борется против литературы, литературного письма, «чтобы заработать право для себя (и для всех) твердой ногой вступить в дом, принадлежащий человеку» ${ }^{147}$.

Если Роб-Грийе стремится освободить произведение от гуманистических и метафизических смыслов, для Кортасара, «как и для всех остальных испаноамериканских писателей, роман в качестве сложного, а иногда даже вычурного, инструмента служит гуманизму, нацеленному на создание нового понимания человека и жизни» ${ }^{148}$. Примечательно, что через гуманизм Кортасар определяет экзистенциализм и сюрреализм - две главных, с его точки зрения, мировоззренческих системы современности. Экзистенциализм - «героический гуманизм» - и сюрреализм - «магический гуманизм» - движутся навстречу друг другу, и их синтез возвещает «возвращение человека в его царство» ${ }^{149}$.

Если Роб-Грийе был «соглядатаем», Кортасар стремился быть «ясновидцем». В 116 главе «Игры в классики» говорится: «Довольно романов гедонистических, где все разжевано, романов с психологией. Надо стремиться к максимуму, стать voyant, как хотел Рембо. Романист гедонистического склада - не более, чем voyeur. С другой стороны,

146 García Canclini, N. Cortázar: una antropología poética. Buenos Aires: Ed. Nova, 1986: 9.

147 Cortázar, J. Rayuela: 613.

148 Alazraki, J. Hacia Cortázar: aproximaciones a su obra: 202.

149 Cortázar, J. Obra crítica I: 128. 
хватит чисто описательной техники, хватит романов “поведения” простых киносценариев, не дающих свободы образам» ${ }^{150}$. В этом призыве - две составляющих. С одной стороны, Морелли очевидным образом отмежевывается от массовой, потребительской литературы. Вместе с тем слово "vоуеur" отсылает к названию второго романа Роб-Грийе, а упоминание киносценариев - как к его художественному методу, так и к кинематографической деятельности. Интересно, что Андре Клавель в одном из интервью с Бютором также говорил о том, что новороманисты не были “voyants": «Вы были в большей степени геометрами, чем ясновидцами - в том смысле, который вкладывал в это слово Рембо» ${ }^{151}$.

\section{2. Роман как поиск}

При всех различиях, существующих между новороманистами, объединяет их представление о литературе как поиске. Слово «поиск» (recherche) вынесено в заголовок двух важнейших эссе Бютора: «Роман как поиск» (“Le Roman comme recherche”) и «Исследование о технике романа» ("Recherches sur la technique du roman"). Через поиск определяет сущность романа Роб-Грийе. Вокруг концепции поиска строится первая лекция Саррот, прочитанная ею в Лозаннском университете в 1959 г. Однако цель поиска у каждого - своя.

Основываясь на многозначности слова "recherche", заголовок эссе Бютора можно перевести двояко: «Роман как поиск» и «Роман как исследование». «Научное» значение слова реализуется в образе романа-лаборатории: по определению Бютора, роман - это «истинно феноменологическая область, идеальное место для изучения того, как реальность нам является или может быть явлена, и потому роман есть лаборатория рассказа» ${ }^{152}$. Целью поиска романиста должны быть «новые формы», с помощью которых он сможет открыть и описать новые явления реальности. Роман, таким образом, является одновременно и инструментом поиска, и полем научного исследования.

\footnotetext{
150 Ibid.: 658 .

151 Butor, M. Curriculum vitae: 104.

152 Butor, M. Essais sur le roman: 9. Ср. перевод Н. Бунтман: роман - это «особая феноменологическая область, особое место для изучения того, как реальность нам является или может быть явлена, и потому роман есть лаборатория рассказа» (Бютор М. Роман как исследование. С. 32). В оригинале в обоих случаях "par excellence".
} 
Примечательно, что, рассуждая о романе, Кортасар так же, как и Бютор, прибегает к научному образному ряду. Отстаивая право писателя на эксперимент, он приводит следующий довод: «Если физика и математика может идти от гипотезы к опыту, может даже постулировать совершенно иррациональные идеи, чтобы потом достичь результата, подтверждаемого практикой, то почему романист должен отказываться от гипотетических структур, от чистой схемы...?» ${ }^{153}$ Роман «62. Модель для сборки» был для писателя, по его собственным словам, «лабораторией», в которой он пытался организовать «рационально несовместимые материи» ${ }^{154}$.

Концепция поиска, изложенная Роб-Грийе в эссе «Новый роман, новый человек» (“Nouveau Roman, homme nouveau”), несколько отличается от той, что представлена в эссе «От реализма - к реальности». Если в первом утверждается связь литературного произведения с внеположной ему реальностью, его способность наделять мир смыслами ${ }^{155}$, то во втором делается больший акцент на самой реальности письма: «Роман - это вообще не орудие. Он задумывается отнюдь не с целью выполнить какую-то определенную работу. Он не служит для того, чтобы представлять, выражать какие-то существующие до него и вне его вещи. Он занят не выражением, а поиском. И то, что он ищет, - это он сам» ${ }^{156}$.

Натали Саррот считает, что романист, как и любой человек искусства, должен осуществлять поиск «новой реальности». В современном искусстве этой новой реальностью становится «ощущение в чистом виде»: музыка освободилась от чувств и мелодии, чтобы выделить чистый звук; в абстрактной живописи внимание зрителя обращается на

153 Цит. по: Тертерян И.А. Теоретические искания и проблема национального своеобразия литературы в Латинской Америке // Теории, школы, концепции. Художественный процесс и идеологическая борьба. М.: Наука, 1975. С. 240.

154 Cortázar, J. "Literatura en la revolución y revolución en la literatura: algunos malentendidos a liquidar": 70.

155 Современный роман - «это поиск, но такой поиск, который сам создает собственные смыслы по мере своего продвижения вперед. Есть ли какой-либо смысл у действительности? Современный художник не может ответить на этот вопрос: ему об этом ничего не известно. Он может сказать только, что эта действительность, возможно, обретет некий смысл, когда он закончит свое произведение» (Роб-Грийе А. Романески. С. 592).

156 Роб-Грийе А. Романески. С. 601. 
краски и формы; поэзия освобождается от риторики и рифмы; а роман борется с властью персонажа и сюжета ${ }^{157}$.

Можно сказать, что в названии рассказа «Преследователь» заложена самохарактеристика Кортасара: как в жизни, так и в творчестве он, не удовлетворенный наличным бытием, все время искал - исследовал «новую реальность», абсолют, новые смыслы и ценности. Как говорится в 141 главе «Игры в классики»: «...вместе с предчувствием полной нигилистичности произведения с некоторым запозданием могло родиться подозрение, что не таков был замысел Морелли, что саморазрушение, заключенное в каждой частице книги, подобно поискам [курсив мой - A.Г.] благородного металла среди сплошной пустой породы» ${ }^{158}$. Этот «благородный металл» для Кортасара представляет собой новую этику и новую метафизику. Посредством романа писатель должен искать «иные ценности», выхода в иную реальность (“уonder”). Словно полемизируя с Роб-Грийе, Кортасар говорит от лица Морелли, что роман, ограничивающий читателя протяженностью текста, лишает его возможности осуществлять этот поиск.

$$
* * *
$$

Кортасар начал искать новые пути в литературе независимо от французских новороманистов. Ориентируясь на европейскую традицию, писатель находит в ней как вдохновляющие образцы, с которыми он соотносит свое творчество, так и изжившие себя формы, от которых он отмежевывается. Так, еще до знакомства с «новым романом», Кортасар закладывает основы своей поэтики, определяющие своеобразие его собственных романов («Выигрыши», «Игра в классики», «62. Модель для сборки», «Книга Мануэля»).

Теоретические работы новороманистов очень заинтересовали Кортасара, так как он разделял их стремление освободиться от условностей романа бальзаковского типа и трафаретных форм, создать своего рода «антироман». Действительно, между художественными принципами новороманистов и художественными принципами Кортасара обнаруживаются многочисленные параллели - вплоть до общности формулировок. Но это сходство не скрадывает своеобразия

157 Sarraute, N. Evves complètes: 1673.

158 Cortázar, J. Rayuela: 717. 
кортасаровской поэтики, в основе которой лежит его особое мировидение, осуществляемый им на протяжении всего творчества поиск новой этики и новой метафизики.

Вместе с новороманистами Кортасар борется с психологизмом, отказываясь от модели привычно мотивированного поведения персонажей и от авторской интерпретации - ближе всего при этом ему оказывается Натали Саррот. Кортасар разделяет стремление писательницы выйти на внеличностный психологический уровень, но, если Саррот «движется» вглубь человеческой психики, Кортасар хочет обнаружить внешние силы, влияющие на человеческую жизнь, закономерности иного порядка - так называемые «фигуры».

Если нарушения пространственно-временного континуума у Роб-Грийе свидетельствуют об автономной природе текста, у Кортасара они прямо соотносятся с его представлениями о существовании другой реальности, в которой не действуют аристотелевские законы логики и евклидовы законы пространства. Глубина метафизического измерения кортасаровской художественной реальности определяет ее отличие от, на первый взгляд, очень на нее похожей художественной реальности Бютора.

Основополагающим как для Кортасара, так и для новороманистов является стремление к непосредственности, желание освободить человека от гнета готовых смыслов. Именно поэтому столь важной в «новом романе» становится роль читателя. Но если новороманисты осмысляли свою деятельность прежде всего в рамках искусства, Кортасар делал акцент на гносеологической, экзистенциальной функции литературы. Литература для него - средство поиска «иных ценностей».

Результаты проведенного сопоставительного анализа теоретических установок Кортасара и теоретических установок новороманистов подтверждают сформулированную нами в самом начале гипотезу: Кортасар и новороманисты двигались в одном направлении, но в разных плоскостях. Кортасаровскую плоскость можно определить как метафизическую и этическую, плоскость новороманистов, при всех их различиях - как эстетическую. 


\section{ЛИТЕРАТУРА}

Андреев Л.Г. Жан-Поль Сартр. Свободное сознание и ХХ век. М.: Гелеос, 2004.

Андреев Л.Г. Современная литература Франции. 60-е гг. М.: Изд-во Московского университета, 1977.

Бютор М. Изменение. М.: Художественная литература, 1983.

Бютор М. Роман как исследование. М.: Изд-во МГУ, 2000.

Гонтар М. Постмодернизм во Франции: определение, критерии, периодизация // Постмодернизм: парадоксы бытия. Ежегодник «Человек. Образ и сущность». М.: ИНИОН РАН, 2006. С. 155-169.

Зонина Л.А. Тропы времени: заметки об исканиях французских романистов (60-70-е гг.). М.: Художественная литература, 1984.

Kopmacap X. Игра в классики. М.: АСТ; Владимир: ВКТ, 2011.

Kopmacap X. Игра в классики. Рассказы. М.: НФ «Пушкинская библиотека»- АСТ, 2003.

Kopmacap X. Письма к издателю. М.: Центр книги Рудомино, 2012.

Косиков Г.К. Собрание сочинений. Т.2. М.: Центр книги Рудомино, 2012.

Кутейщикова В.Н., Осповат Л.С. Новый латиноамериканский роман: 50-70-е гг. М.: Советский писатель, 1983.

Писатели Латинской Америки о литературе. М.: Радуга, 1982.

Пьеге-Гро Н. Введение в теорию интертекстуальности. М.: ЛЕНАНД, 2015.

Роб-Грийе А. Романески. М.: Ладомир, 2005.

Саррот H. Тропизмы. Эра подозрения. М.: Полинформ-Талбури, 2000.

Сартр Ж-П. Ситуации. М.: Ладомир, 1998.

Тертерян И.А. Главный роман Хулио Кортасара // Кортасар Х. Игра в классики. М.: Художественная литература, 1986. С. 5-24.

Тертерян И.А. Теоретические искания и проблема национального своеобразия литературы в Латинской Америке // Теории, школы, концепции. Художественный процесс и идеологическая борьба. М.: Наука, 1975. С. 215-241.

Alazraki, J. Hacia Cortázar: aproximaciones a su obra. Barcelona: Editorial Anthropos, 1994.

Babín, M.T. "La antinovela en Hispanoamérica.” Revista Hispánica Moderna 3/4 (Jul.-Oct. 1968): 523-532.

Barrenechea, A.M. "La estructura de Rayuela." Litterae Hispanae et Lusitanae (1968): 69-84.

Barthes, R. Essais critiques. P.: Éditions du Seuil, 1964.

Bjurström, C.G. "Entretien avec Julio Cortázar." Archivo Julio Cortázar. CRLA Archivos (Poitiers). Online at www.mshs.univ-poitiers.fr/crla/contenidos/Cortazar/ image.php?Id_img $=5292 \&$ Code $=28.007$

Borges, J.L. Discusión. Buenos Aires: Emecé Editores, 1972.

Butor, M. Curriculum vitae: entretiens avec André Clavel. P.: Plon, 1996.

Butor, M. Essais sur le roman. P.: Gallimard, 1975.

Butor, M. L'emploi du temps. P.: Les Éditions de Minuit, 1957. 
Coloquio sobre la novela hispanoamericana. México: Fondo de Cultura Económica, 1967.

Cortázar, J. "Literatura en la revolución y revolución en la literatura: algunos malentendidos a liquidar." Literatura en la revolución y revolución en la literatura. México: Siglo XXI editores, 1970.

Cortázar, J. 62/Modelo para armar. México: Punto de lectura, 2013.Cortázar, J. "Posición de la novela." Cuadernos Americanos 52:4 (Julio-agosto 1950): 223-243.

Cortázar, J. Los premios. Madrid: Punto de lectura, 2007.

Cortázar, J. Obra crítica I. Madrid: Alfaguara, 1994.

Cortázar, J. Obra crítica II. Madrid: Alfaguara, 1994.

Cortázar, J. Rayuela, ed. crítica de Julio Ortega y Saúl Yurkievich. Madrid: ALLCA XX, 1991.

Cortázar, J. Rayuela. Madrid: Cátedra, 2012.

Cortázar, J. Último round. México: Siglo XXI Editores, 1969.

Cortázar, J. La vuelta al día en ochenta mundos. México: Siglo XXI Editores, 1968.

Duncan J.A. "Mirrors and labyrinths, some comparisons between Cortázar and the "nouveau roman'." Archivo Julio Cortázar. CRLA Archivos (Poitiers). Online at http:// www.mshs.univ-poitiers.fr/crla/contenidos/Cortazar/image. php?Id_img $=3159 \&$ Code $=16.05$

Fuentes, C. La nueva novela hispanoamericana. México: Editorial Joaquín Mortiz, 1974. Nova, 1986

García Canclini, N. Cortázar: una antropología poética. Buenos Aires: Ed.

González Bermejo E. Conversaciones con Cortázar. Barcelona: Edhasa, 1978.

Harss L. Los nuestros. Buenos Aires: Editorial Sudamericana, 1966.

Hernández, A.M. “Conversación con Julio Cortázar.” Cortázar, J. Rayuela, ed. Julio Ortega y Saúl Yurkievich. Madrid: ALLCA XX, 1991: 728-735.

Kalda, A. "Julio Cortázar et Monteforte Toledo: les deux tendances de la littérature ibéro-américaine." Arts 922 (1963): 2.

La littérature en France depuis 1945. Paris-Montréal: Bordas, 1970.

Nouveau roman: hier, aujourd'hui. T.1. Problèmes généraux. P.: Hermann Éditeurs, 2011.

Perrot, D. “"62-Maquette à monter' de Julio Cortázar : un «nouveau roman?” Archivo Julio Cortázar. CRLA Archivos (Poitiers). Online at http://www.mshs.univpoitiers.fr/crla/contenidos/Cortazar/fiche.php?Code $=16.027 \&$ Cle $=$ catalogue 1981.

Picón Garfield, E. Cortázar por Cortázar. Xalapa: Universidad Veracruzana,

Pollman, L. "La nueva novela hispanoamericana. Un balance definitorio." Revista chilena de literatura 34 (Nov. 1989): 77-93.

"Por una novela novelesca y metafísica." Mundo Nuevo 5 (Nov. 1966 ): 5-21.

Pollmann, L. La "nueva novela” en Francia y en Iberoamérica. Madrid: Gredos, 1971.

Prego, O. Fascinación de las palabras: Conversaciones con Julio Cortázar. Barcelona: Muchnik Editores, 1985. 
Robbe-Grillet, A. Pour un nouveau roman. P.: Minuit, 1963.

Sarraute, N. L'Ère du soupçon. P.: Gallimard, 1956.

Sarraute, N. Le Planétarium. P.: Gallimard, 1959.

Sarraute, N. Evres complètes. P.: Gallimard, 1996.

Sartre, J.-P. "Préface." Sarraute, N. Portrait d'un inconnu. P.: Gallimard, 1956: 7-14. Online at www.mshs.univ-poitiers.fr/crla/contenidos/Cortazar/image. php?Id_img $=5292 \&$ Code $=28.007$

\section{REFERENCES}

Alazraki, J. Hacia Cortázar: aproximaciones a su obra. Barcelona: Editorial Anthropos, 1994.

Andreev, L.G. Sovremennaia literatura Frantsii. 60ye gg. [Modern French Literature in the 60s] Moscow: Izdatel'stvo Moskovskogo universiteta Publ., 1977. (In Russ.)

Andreev, L.G. Zhan-Pol Sartr. Svobodnoe soznanie i XX vek. [Jean-Paul Sartre. A Free Mind and the XX century] Moscow: Geleos Publ., 2004. (In Russ.)

Babín, M.T. "La antinovela en Hispanoamérica." Revista Hispánica Moderna 3/4 (Jul.-Oct. 1968): 523-532.

Barrenechea, A.M. "La estructura de Rayuela." Litterae Hispanae et Lusitanae (1968): 69-84.

Barthes, R. Essais critiques. P.: Éditions du Seuil, 1964.

Bjurström, C.G. "Entretien avec Julio Cortázar.” Archivo Julio Cortázar. CRLA Archivos (Poitiers). Online at www.mshs.univ-poitiers.fr/crla/contenidos/Cortazar/ image.php?Id_img $=5292 \&$ Code $=28.007$

Borges, J.L. Discusión. Buenos Aires: Emecé Editores, 1972.

Butor, M. Curriculum vitae: entretiens avec André Clavel. P.: Plon, 1996.

Butor, M. Essais sur le roman. P.: Gallimard, 1975.

Butor, M. Izmenenie. [Modification] Moscow: Khudozhestvennaia literatura Publ., 1983. (In Russ.)

Butor, M. L'emploi du temps. P.: Les Éditions de Minuit, 1957.

Butor, M. Roman kak issledovanie. [Novel as Research] Moscow: Izdatel'stvo Moskovskogo universiteta Publ, 2000. (In Russ.)

Coloquio sobre la novela hispanoamericana. México: Fondo de Cultura Económica, 1967.

Cortázar, J. Igra v klassiki. [Hopscotch] Moscow: AST Publ.; Vladimir: VKT Publ., 2011. (In Russ.)

Cortázar, J. Igra v klassiki. Rasskazy. [Hopscotch. Stories] Moscow: NF "Pushkinskaia biblioteka” Publ., AST Publ., 2003. (In Russ.)

Cortázar, J. "Literatura en la revolución y revolución en la literatura: algunos malentendidos a liquidar." Literatura en la revolución y revolución en la literatura. México: Siglo XXI editores, 1970.

Cortázar, J. 62/Modelo para armar. México: Punto de lectura, 2013.Cortázar, J. "Posición de la novela." Cuadernos Americanos 52:4 (Julio-agosto 1950): 223-243. 
Cortázar, J. Los premios. Madrid: Punto de lectura, 2007.

Cortázar, J. Obra crítica I. Madrid: Alfaguara, 1994.

Cortázar, J. Obra crítica II. Madrid: Alfaguara, 1994.

Cortázar, J. Rayuela, ed. crítica de Julio Ortega y Saúl Yurkievich. Madrid: ALLCA XX, 1991.

Cortázar, J. Rayuela. Madrid: Cátedra, 2012.

Cortázar, J. Último round. México: Siglo XXI Editores, 1969.

Cortázar, J. La vuelta al día en ochenta mundos. México: Siglo XXI Editores, 1968.Duncan, J.A. "Mirrors and Labyrinths, Some Comparisons Between Cortázar and the 'Nouveau Roman'." Archivo Julio Cortázar. CRLA Archivos (Poitiers). Online at http:// www.mshs.univ-poitiers.fr/crla/contenidos/Cortazar/image. php?Id_img $=3159 \&$ Code $=16.05$

Fuentes, C. La nueva novela hispanoamericana. México: Editorial Joaquín Mortiz, 1974. Nova, 1986.

García Canclini, N. Cortázar: una antropología poética. Buenos Aires: Ed.

Gontard, M. "Postmodernizm vo Frantsii: opredelenie, kriterii, periodizatsiia." ["Postmodernism in France: Definition, Criteria, Periodization."] Postmodernizm: paradoksy bytiia. Ezhegodnik "Chelovek. Obraz i sushchnost" [Postmodernism: the Paradoxes of Being. Annuary «Human. Image and Essence»] Moscow, INION RAN Publ., 2006: 155-169. (In Russ.)

González Bermejo, E. Conversaciones con Cortázar. Barcelona: Edhasa, 1978.

Harss, L. Los nuestros. Buenos Aires: Editorial Sudamericana, 1966.

Hernández, A.M. “Conversación con Julio Cortázar.” Cortázar, J. Rayuela, ed. Julio Ortega y Saúl Yurkievich. Madrid: ALLCA XX, 1991: 728-735.

Kalda, A. "Julio Cortázar et Monteforte Toledo: les deux tendances de la littérature ibéro-américaine.” Arts 922 (1963): 2.

Kosikov, G.K. Sobranie sochinenii. T.2. [Complete works.] T.2 Moscow: Tsentr knigi Rudomino Publ., 2012. (In Russ.)

Kuteishchikova, V.N., Ospovat, L.S. Novyi latinoamerikanskii roman: 50-70ye gg. [New Latin American Novel: 50-70s] Moscow: Sovetskii pisatel Publ., 1983. (In Russ.)

La littérature en France depuis 1945. Paris-Montréal: Bordas, 1970.

Nouveau roman: hier, aujourd'hui. T.1. Problèmes généraux. P.: Hermann Éditeurs, 2011.

Perrot, D. “"62-Maquette à monter' de Julio Cortázar : un «nouveau roman?” Archivo Julio Cortázar. CRLA Archivos (Poitiers). Online at http://www.mshs.univ-poitiers.fr/crla/contenidos $/$ Cortazar/fiche.php?Code $=16.027 \&$ Cle $=$ catalogue

Picón Garfield, E. Cortázar por Cortázar. Xalapa: Universidad Veracruzana, 1981.

Piégay-Gros, N. Vvedenie v teoriiu intertekstualnosti. [An Introduction to the Theory of Intertextuality] Moscow: LENAND Publ., 2015. (In Russ.)

Pisateli Latinskoi Ameriki o literature. [Latin American Writers on Literature] Moscow: Raduga Publ., 1982. (In Russ.) 
Pollman, L. "La nueva novela hispanoamericana. Un balance definitorio." Revista chilena de literatura 34 (Nov. 1989): 77-93. 1971.

Pollmann, L. La “nueva novela” en Francia y en Iberoamérica. Madrid: Gredos,

“Por una novela novelesca y metafísica." Mundo Nuevo 5 (Nov. 1966 ): 5-21.

Prego, O. Fascinación de las palabras: Conversaciones con Julio Cortázar. Barcelona: Muchnik Editores, 1985.

Robbe-Grillet, A. Pour un nouveau roman. P.: Minuit, 1963

Robbe-Grillet, A. Romaneski. [Romanesques] Moscow: Ladomir Publ., 2005. (In Russ.)

Sarraute, N. L'Ère du soupçon. P.: Gallimard, 1956.

Sarraute, N. Le Planétarium. P.: Gallimard, 1959.

Sarraute, N. Evres complètes. P.: Gallimard, 1996.

Sarraute, N. Tropizmy. Era podozreniia. [Tropismes. The Age of Suspicion] Moscow: Polinform-Talburi Publ., 2000. (In Russ.) $7-14$.

Sartre, J.-P. "Préface.” Sarraute, N. Portrait d'un inconnu. P.: Gallimard, 1956:

Sartre, J.-P. Situatsii. [Situations] Moscow: Ladomir Publ., 1998. (In Russ.)

Terterian, I.A. “Glavnyi roman Khulio Kortasara.” [“Julio Cortázar's Central Novel.”] Cortázar, J. Igra v klassiki. [Hopscotch] Moscow: Hudozhestvennaia literatura Publ., 1986: 5-24. (In Russ.)

Terterian, I.A. "Teoreticheskie iskaniia i problema natsionalnogo svoeobraziia literatury v Latinskoi Amerike." ["Theoretical Searchings and the Problem of National Originality of Literature in Latin America."] In Teorii, shkoly, kontseptsii. Khudozhestvennyi protsess i ideologicheskaia borba. [Theories, Schools, Concepts. Literary Process and Ideological Struggle] Moscow: Nauka Publ., 1975: 215-241. (In Russ.)

Zonina, L.A. Tropy vremeni: Zametki ob iskaniiakh frantsuzskikh romanistov (60-70ye gg.). [The Paths of Time: Notes on the Searchings of the French Novelists (60-70s)] Moscow: Khudozhestvennaia literatura Publ., 1984. (In Russ.) 